\title{
Denitrification in sediments of the River Colne estuary, England
}

\author{
L. F. Dong, D. C. O. Thornton, D. B. Nedwell*, G. J. C. Underwood \\ Department of Biological Sciences, John Tabor Laboratories, University of Essex, Colchester CO4 3SQ, Essex, United Kingdom
}

\begin{abstract}
The River Colne is a muddy macrotidal estuary on the east coast of England, with strong decreasing gradients of $\mathrm{NO}_{3}{ }^{-}$and $\mathrm{NH}_{4}{ }^{+}$down the estuary due to inputs from the river and upstream sewage treatment works. The rates of uncoupled $\left(D_{\mathrm{w}}\right)$ and coupled $\left(D_{\mathrm{n}}\right)$ denitrification in the sediments at 4 sites were measured monthly by ${ }^{15} \mathrm{~N}$ isotope-pairing technique from October 1996 to March 1998. There was a significant spatial and temporal variation in the rates of $D_{\mathrm{w}}$ and $D_{\mathrm{n}}$. The highest rates were observed at Site 1 and the lowest at Site 4, corresponding to the highest $\mathrm{NO}_{3}{ }^{-}$concentrations in the water column and highest organic contents in the sediments at Site 1 and the lowest at Site 4. Short-term kinetic experiments showed that rates of $D_{\mathrm{w}}$ increased with increasing $\mathrm{NO}_{3}{ }^{-}$concentration in the water column, up to $500 \mathrm{\mu M} \mathrm{NO}_{3}{ }^{-}$at Site 2 (the middle site along the estuary), and were not saturated up to $600 \mu \mathrm{M} \mathrm{NO}_{3}{ }^{-}$at Site 1 or $180 \mu \mathrm{M} \mathrm{NO}_{3}{ }^{-}$at Site 4. Field observations and kinetics experiments indicated a large sediment potential for $D_{\mathrm{w}}$ at all sites. Nitrate availability limited the rates of $D_{\mathrm{w}}$ and was the main factor regulating the rates of $D_{\mathrm{w}}$ in this estuary. It was calculated that 32 to $44 \%$ of total oxidised nitrogen inputs or 20 to $25 \%$ of the total inorganic nitrogen inputs (total oxidised nitrogen + ammonium) into the estuary by the River Colne and the sewage treatment works were removed from the estuary by uncoupled denitrification $\left(D_{\mathrm{w}}\right)$ and total denitrification $\left(D_{\mathrm{w}}+D_{\mathrm{n}}\right)$ respectively, in the sediments before they were transported into the North Sea. Microphytobenthos, mainly diatoms, assimilated $4.1 \%$ of the ammonium inputs or $2.3 \%$ of total inorganic nitrogen inputs into the estuary and temporarily retained the assimilated nitrogen in the estuary. They also affected the rates of denitrification in a complex manner, by regulating the depth of oxygen penetration by photosynthetic oxygen production and respiratory oxygen uptake. Photosynthesis inhibited the rates of $D_{\mathrm{w}}$ but stimulated $D_{\mathrm{n}}$. The overall effect of microphytobenthos on denitrification was to increase the percentages of $D_{\mathrm{n}}$ in the total denitrification. The loads of nitrogen through the River Colne estuary to the North Sea was significantly attenuated by the removal of nitrate from the water column by $D_{\mathrm{w}}$ and of nitrate produced from ammonium via nitrification in the sediment by $D_{\mathrm{n}}$.
\end{abstract}

KEY WORDS: Denitrification · Primary production $\cdot$ Microphytobenthos $\cdot$ Benthic diatoms $\cdot$ Estuaries Nitrogen

Resale or republication not permitted without written consent of the publisher

\section{INTRODUCTION}

Denitrification in estuarine sediment is known to be capable of removing significant quantities of nitrate from the water column, providing a sink for nitrogen in aquatic environments, and thereby playing an impor-

*Corresponding author. E-mail: nedwd@essex.ac.uk tant role in ameliorating the degree of eutrophication in waters subjected to input of nitrogen compounds (Nedwell 1975, Billen et al. 1985, Seitzinger 1988, Rysgaard et al. 1995, Nedwell \& Trimmer 1996, Nixon et al. 1996, Ogilvie et al. 1997, Trimmer et al. 1998, Nedwell et al. 1999). Denitrification in sediments is supported both by nitrate diffusing from the overlying water and by nitrate produced within the sediment by nitrification (Vanderborght \& Billen 1975, Nishio et al. 
1983, Jenkins \& Kemp 1984, Henriksen \& Kemp 1988). Diffusion of nitrate from overlying water into an anoxic layer of sediment where denitrification occurs is primarily governed by a concentration gradient determined by the water nitrate concentration and the length of the diffusion path through the oxic zone (Christensen et al. 1990). Nitrification activity in sediment is mainly controlled by the availability of ammonium and oxygen (Hansen et al. 1981, Henriksen et al. 1981).

The quantitative significance of denitrification in attenuating the flux of nitrogen through estuaries into the sea is, as yet, poorly defined. In some estuaries the attenuation of the nitrogen load seems to be significant (Billen et al. 1985, Seitzinger 1988, 1990, Nedwell \& Trimmer 1996, Ogilvie et al. 1997), while in others it appears to be small (Nielsen et al. 1995). The degree of attenuation of the nitrogen flux within an estuary is positively related to the freshwater flushing time of the estuary (Balls 1994, Nixon et al. 1996), and can also be influenced by other factors which affect benthic denitrification and nitrification. These factors include bioturbation by benthic infauna (Pelegri et al. 1994, Pelegri \& Blackburn 1995, 1996, Gilbert et al. 1998, Svensson 1998), nitrate concentration in the overlying water column and oxygen penetration depth (Christensen et al. 1990), benthic microalgae (RisgaardPetersen et al. 1994, Rysgaard et al. 1995) and availability of ammonium and oxygen (Blackburn 1996).

In order to better understand the quantitative significance of denitrification in removal of nitrogen from an estuary, environmental factors which may be involved in regulating denitrification need to be investigated. The River Colne is a hypernutrified estuary, with strong decreasing gradients of $\mathrm{NO}_{3}{ }^{-}$and $\mathrm{NH}_{4}{ }^{+}$in the water column and organic contents in the sediments down the estuary. The estuary is also characterised by the presence of microphytobenthos on the surface of the sediment. So the purpose of the present study was to investigate the effects of nitrate availability in the water column and the benthic primary producers on denitrification in a North Sea estuary on the east coast of England.

\section{MATERIALS AND METHODS}

Sampling locations. The Colne estuary is a small muddy macrotidal ( 3 to $5 \mathrm{~m}$ ) estuary (Fig. 1) on the east coast of England, entering the North Sea at Brightlingsea $\left(51^{\circ} 45^{\prime} \mathrm{N}, 01^{\circ} 03^{\prime} \mathrm{E}\right)$. The estuary catchment is $500 \mathrm{~km}^{2}$, of which the River Colne drains $300 \mathrm{~km}^{2}$, much of which is rich arable land. The estuary exhibits strong increasing gradients of both $\mathrm{NO}_{3}{ }^{-}$and $\mathrm{NH}_{4}{ }^{+}$ concentrations with distance upstream (King \& Nedwell 1987, Ogilvie et al. 1997) as a result of inputs from the River Colne and a major sewage treatment work at Colchester. Four benthic sampling sites were selected (Fig. 1), covering the full ranges of the estuarine nutrient gradients and sediment types along the estuary. At Sites 2 and 3 in the central stretch of the estuary, where the largest areas of intertidal mud flat were found, both high-shore (mean high water) and low-shore (mean low water) stations $(2 \mathrm{H}, 2 \mathrm{~L}, 3 \mathrm{H}$ and $3 \mathrm{~L}$ ) were sampled.

Sediment characteristics. Samples of sediment were taken from the sites for measurements of porosity, sediment particle size and organic content of the sediments. The porosity was determined from the dry weights and wet weights of known volumes of sediment and expressed in terms of $\mathrm{ml}_{2} \mathrm{O}$ per ml sediment. The sediment particle size was measured by sieving (mesh size $65 \mu \mathrm{m}$ ). The sediment organic content was analysed with a CHN analyser (Model 2400, Perkin-Elmer, Beaconsfield, UK) (See Nedwell \& Trimmer 1996 for details of methods used).

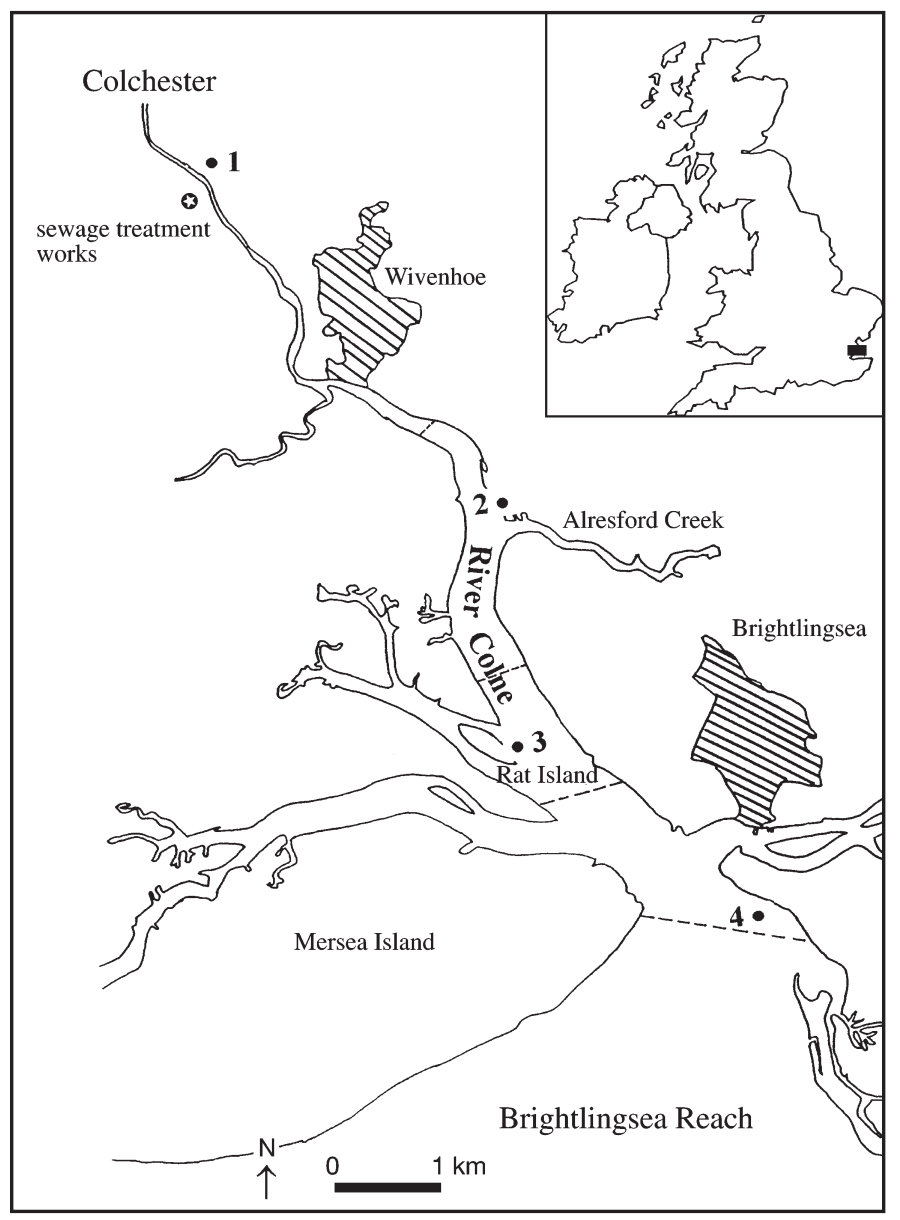

Fig. 1. Map of Colne estuary on east coast of England, showing positions of 4 sampling sites. At Sites 2 and 3 two stations (high shore and low shore) were sampled. Dashed lines divide sectors in estuary 
Nutrient concentration in water column. Site water was collected at high tide. Water samples were filtered through glass-fibre filters (GF/F, Whatman, UK) and put into a deep freezer for later analysis. The nitrate, nitrite and ammonium concentrations (Kirkwood 1996) in the water samples were analysed by a nutrient autoanalyser (Skalar Analytical B.V., Breda, The Netherlands). Salinity was measured by an refractory meter (Leica, New York, USA).

Chlorophyll a content in surface sediment. The sediment samples from the top $50 \mathrm{~mm}$ layer of sediments were collected for chlorophyll a analysis (see Underwood et al. 1995). About $100 \mathrm{mg}$ of freeze-dried sediment was extracted in $4 \mathrm{ml} \mathrm{MgCO}_{3}$-buffered $100 \%$ methanol for $24 \mathrm{~h}$ at $4^{\circ} \mathrm{C}$ in the darkness. Following centrifugation for $15 \mathrm{~min}$ at $2000 \times g$, absorbances of the supernatant was measured at 665 and $750 \mathrm{~nm}$ using a spectrophotometer (CECIL, Cambridge, UK) followed by acidification. Chlorophyll a concentration was calculated by the equation of Stal et al. (1984).

Oxygen flux across sediment-water interface. Triplicate sediment cores ( $30 \mathrm{~cm}$ deep) were collected from each site with Perspex core tubes $(65 \mathrm{~cm}$ long $\times 8 \mathrm{~cm}$ i.d.). On return to the laboratory the water volume in the core tube above the sediment was adjusted to $500 \mathrm{ml}$, and the cores were immersed in aerated site water at in situ water temperature to re-equilibrate overnight. Next day, the rates of oxygen uptake or evolution were measured in the light $\left(500 \mu \mathrm{mol} \mathrm{m} \mathrm{m}^{-2} \mathrm{~s}^{-1}\right.$; this is the light used for all experiments in this study) and dark at in situ temperature. 'Light' incubations were performed at a time corresponding to the time of low tide, so the natural migratory cycle of benthic diatoms would ensure that they were present at the surface of the sediment when the measurements were made. The water column in each tube was stirred with an induction motor driving a magnetic follower (Rank Brothers Ltd, Cambridge, UK) at 300 rpm. (Preliminary experiments showed that benthic oxygen uptake was unaffected by stirring rates over the range 300 to $900 \mathrm{rpm})$. Triplicate water samples were collected at the beginning and end of the incubation from each core tube, and the oxygen concentrations were measured by Winkler titration (Strickland \& Parsons 1972).

Vertical concentration profiles of dissolved oxygen in sediments. These were determined in sediment cores in the light and dark with a very fine, glass oxygen microelectrode (home-made, not commercially available). The microelectrode was calibrated in aerated site water $\left(100 \%\right.$ of $\mathrm{O}_{2}$ saturation) and in water with added sodium dithionite $\left(0 \%\right.$ of $\mathrm{O}_{2}$ saturation). It was then introduced into water overlying the sediment and down into sediment. The vertical movement of the electrode was controlled by a stepping motor linked to a micromanipulator. The stepping motor was con- trolled by a computer programme (TiePie Engineering, Leeuwarden, The Netherlands) to give $20 \mu \mathrm{m}$ depth steps at $2 \mathrm{~s}$ intervals.

Measurement of denitrification with ${ }^{15} \mathrm{NO}_{3}{ }^{-}$. The isotope-pairing technique (Nielsen 1992) was used to measure sedimentary denitrification from both external $\mathrm{NO}_{3}{ }^{-}$, derived by transport into the sediment from the water column $\left(D_{\mathrm{w}}\right)$, and from $\mathrm{NO}_{3}^{-}$generated within the sediment by nitrification $\left(D_{\mathrm{n}}\right)$. Cores of sediment $(\sim 10 \mathrm{~cm}$ deep) were collected in Perspex tubes ( $3.4 \mathrm{~cm}$ i.d. $\times 22 \mathrm{~cm}$ length) from each site. On return to the laboratory, the water above the sediment was carefully replaced with site water. The cores were put in an incubation tank at in situ water temperature and submerged in site water which was vigorously bubbled with air overnight to re-equilibrate. Next day, the rate of denitrification was measured.

Time-course experiments: The measurement of denitrification by the isotope-pairing technique requires addition of ${ }^{15} \mathrm{NO}_{3}{ }^{-}$into the water column overlying sediment. It takes some time for the added ${ }^{15} \mathrm{NO}_{3}{ }^{-}$to mix homogeneously with the ${ }^{14} \mathrm{NO}_{3}{ }^{-}$in the water column and in the sediment. To determine the optimum incubation time for the measurement, time-course experiments were carried out. The incubation time began on addition of $50 \mu \mathrm{M}$ (Site 4) and $100 \mu \mathrm{M}$ (Site 1) of

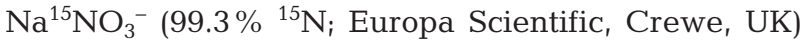
into the water column (where the unlabelled nitrate concentrations were 21 and $295 \mu \mathrm{M}$, respectively, for Sites 4 and 1) of each core, and the core was immediately stoppered. The water columns were stirred at $60 \mathrm{rpm}$ during incubation with small magnetic followers ( $2 \mathrm{~cm}$ length) in the middle of the water column to maintain mixing. Cores were incubated for 15, 30, 45, 60,120 , or $180 \mathrm{~min}$ in a water bath at in situ temperature in the dark. The dissolved $\mathrm{O}_{2}$ in the water column never decreased below $80 \%$ of air saturation. At the end of each incubation, the stopper was removed from each core tube and $\mathrm{ZnCl}_{2}$ solution $(0.5 \mathrm{ml}$ of $50 \% \mathrm{w} / \mathrm{v})$ added to the water column to stop microbial activity; then the sediment and water column were stirred to mix. A sample of the resultant slurry was immediately removed with a syringe and transferred to a $12.5 \mathrm{ml}$ exetainer (Labco, High Wycombe, UK). A further $100 \mu \mathrm{l}$ of $\mathrm{ZnCl}_{2}$ solution was added to the exetainer, which was then sealed. Four ml of water sample in the exetainer was replaced by ultra pure helium. Nitrogen gas in the slurry sample diffused into the helium headspace of the exetainer. The gas samples from the helium headspace were analysed for ${ }^{28} \mathrm{~N}_{2},{ }^{29} \mathrm{~N}_{2}$ and ${ }^{30} \mathrm{~N}_{2}$ using a Europa dual-inlet mass spectrometer fitted with a Europa Automatic Nitrogen and Carbon Analyser system (Europa Automatic Nitrogen, Crewe, UK), located in the NERI laboratory in Silkborg, Denmark. 
The time-course experiments showed that after approx. $45 \mathrm{~min}$ at Site 1 and $30 \mathrm{~min}$ at Site 4, the measured dinitrogen gas production became linear with incubation time. For later measurements, 30 min was given after addition of ${ }^{15} \mathrm{NO}_{3}{ }^{-}$into the water column for the labelled and unlabelled nitrate to mix homogeneously before starting incubation.

It is assumed that addition of ${ }^{15} \mathrm{NO}_{3}{ }^{-}$must not alter the in situ rates of coupled- and uncoupled denitrification based on ${ }^{14} \mathrm{NO}_{3}{ }^{-}$. Thus, it is necessary to verify this assumption and to optimise ${ }^{15} \mathrm{NO}_{3}{ }^{-}$concentrations added. Two approaches were adopted for this purpose. One was to vary ${ }^{15} \mathrm{NO}_{3}{ }^{-}$concentrations but keep ${ }^{14} \mathrm{NO}_{3}{ }^{-}$concentration constant; the other was to vary ${ }^{14} \mathrm{NO}_{3}{ }^{-}$concentrations but keep ${ }^{15} \mathrm{NO}_{3}{ }^{-}$concentration constant. The point is that, ideally, the rate of denitrification based on in situ ${ }^{14} \mathrm{NO}_{3}{ }^{-}$concentration should be independent of the ${ }^{15} \mathrm{NO}_{3}^{-}$concentration added.

Varying ${ }^{15} \mathrm{NO}_{3}^{-}$concentrations but keeping ${ }^{14} \mathrm{NO}_{3}{ }^{-}$ concentration constant: A series of ${ }^{15} \mathrm{NO}_{3}{ }^{-}$concentrations $(10,20,50,75,100,250 \mu \mathrm{M})$ were added into the water column (where the in situ ${ }^{14} \mathrm{NO}_{3}{ }^{-}$concentrations were 21 and $295 \mu \mathrm{M}$, respectively, for Sites 4 and 1) of each core, which was left unstoppered for approx. $30 \mathrm{~min}$ for labelled ${ }^{15} \mathrm{NO}_{3}{ }^{-}$and unlabelled ${ }^{14} \mathrm{NO}_{3}{ }^{-}$to mix homogeneously and equilibrate into the denitrifying layer of the sediments. Each core was then stoppered and incubated for $2 \mathrm{~h}$ at in situ temperature in the dark.

Varying ${ }^{14} \mathrm{NO}_{3}^{-}$concentrations but keeping ${ }^{15} \mathrm{NO}_{3}^{-}$ concentration constant: A solution of ${ }^{14} \mathrm{NO}_{3}{ }^{-}$was added into the overlying water column (nitrate-free artificial seawater) to make a series of the required concentrations, and labelled ${ }^{15} \mathrm{NO}_{3}{ }^{-}$was also added into the cores collected from Site 4 to give constant final concentrations of ${ }^{15} \mathrm{NO}_{3}{ }^{-}$of $50 \mu \mathrm{M}$. The cores were left unstoppered for $30 \mathrm{~min}$ to equilibrate, then stoppered and incubated for 2 to $3 \mathrm{~h}$ at in situ temperature in the dark.

Monthly in situ rates of denitrification: Seven cores were collected from each site every month from October 1996 to March 1998. Of these, 2 cores were used for reference controls and the remaining 5 for incubation using in situ water and at in situ temperature in the dark. From April 1997 to March 1998, a further set of 7 cores were collected from each site and used for incubation in the light $\left(500 \mu \mathrm{mol} \mathrm{m} \mathrm{m}^{-2} \mathrm{~s}^{-1}\right)$. Immediately prior to the start of incubation, $5 \mathrm{ml}$ of column water was withdrawn from each reference core and transferred into $7 \mathrm{ml}$ bijou vials (Bibby Sterilin, Stone, UK) and immediately frozen for later nitrate analysis. To the remaining 5 cores ${ }^{15} \mathrm{NO}_{3}{ }^{-}$was added and they were left for $30 \mathrm{~min}$ to reach equilibrium. Immediately prior to closing the core tubes with stoppers, $2 \mathrm{ml}$ of column water was removed from each core for later nitrate analysis. The ratio of unlabelled and labelled nitrate was calculated by the difference before and after addition of labelled nitrate. Incubation usually lasted 2 to $4 \mathrm{~h}$, depending on the incubation temperature.

Short-term kinetic experiments: Kinetics of denitrification were examined by measurements of denitrification of sediments samples collected from Sites 1 and $2 \mathrm{H}$ at a series of nitrate concentrations (4 replicates for each concentration). After incubation in the dark and light $\left(500 \mu \mathrm{mol} \mathrm{m} \mathrm{m}^{-2} \mathrm{~s}^{-1}\right)$, a $12 \mathrm{ml}$ water sample was taken from each core for measurement of $\mathrm{O}_{2}$ concentration, then $\mathrm{ZnCl}_{2}$ solution $(0.5 \mathrm{ml}$ of $50 \% \mathrm{w} / \mathrm{v})$ was added to the water column and the sediment and water column were stirred to mix. A sample of slurry was removed for isotope measurement. Chlorophyll a content in the top $50 \mathrm{~mm}$ layer of the sediments was also measured (sediment samples for chlorophyll a were collected using separate sediment cores). More details about kinetic experiments are given in the legend to Fig. 9.

The rates of denitrification were calculated according to the equations of Nielsen (1992): $D_{15}=p\left({ }^{15} \mathrm{~N}^{14} \mathrm{~N}\right)+$ $2 p\left({ }^{15} \mathrm{~N}^{15} \mathrm{~N}\right)$, and $D_{14}=p\left({ }^{15} \mathrm{~N}^{14} \mathrm{~N}\right)+2 p\left({ }^{14} \mathrm{~N}^{14} \mathrm{~N}\right)$, where $D_{15}$ and $D_{14}=$ rates of denitrification based on ${ }^{15} \mathrm{NO}_{3}{ }^{-}$ and ${ }^{14} \mathrm{NO}_{3}{ }^{-}$, respectively; and $p\left({ }^{14} \mathrm{~N}^{14} \mathrm{~N}\right), p\left({ }^{15} \mathrm{~N}^{14} \mathrm{~N}\right)$ and $p\left({ }^{15} \mathrm{~N}^{15} \mathrm{~N}\right)=$ rates of production of labelled and unlabelled $\mathrm{N}_{2}$ species. Because the $p\left({ }^{14} \mathrm{~N}^{14} \mathrm{~N}\right)$ cannot be readily measured, estimation of $D_{14}$ was obtained from: $D_{14}=D_{15} \times p\left({ }^{15} \mathrm{~N}^{14} \mathrm{~N}\right) / 2 p\left({ }^{15} \mathrm{~N}^{15} \mathrm{~N}\right)$.

The proportion of $D_{14}$ supported by unlabelled $\mathrm{NO}_{3}{ }^{-}$ from the water column $\left(D_{\mathrm{w}}\right)$ was calculated from: $D_{\mathrm{w}}=$ $D_{15} \times f /(1-f)$, where $f=$ mole fraction of ${ }^{14} \mathrm{NO}_{3}{ }^{-}$in the water column. The coupled nitrification-denitrification $\left(D_{\mathrm{n}}\right)$ was calculated by difference as: $D_{\mathrm{n}}=D_{14}-D_{\mathrm{w}}$.

\section{RESULTS}

\section{Characteristics of sampling sites in Colne estuary}

Sediment characteristics for the 4 sites are shown in Table 1. Sediments at Sites 1, 2 and 3 were fine silt, while at Site 4 , sediments were clay with a very thin layer of fine muddy sand on the surface. The highest organic carbon content and porosity of the sediments were at Site 1 , the lowest at Site 4 . The highest water temperature was $24^{\circ} \mathrm{C}$ in August and the lowest $1.5^{\circ} \mathrm{C}$ in early February. Salinity of the water at Site 1 was variable, in the range of 2 to $17 \%$, depending upon river flow. Salinity at Site 2 was less variable, in the range of 20 to $32 \%$. Salinity at Sites 3 and 4 was rather stable, in the range of 28 to $34 \%$, with a mean value of $32 \%$. 
Table 1. Organic carbon content, porosity, and particle size of top $0.5 \mathrm{~cm}$ of sediments at 4 sites in Colne estuary (data are ranges of 4 replicates)

\begin{tabular}{|c|c|c|c|c|c|}
\hline \multirow{2}{*}{ Parameter } & \multirow{2}{*}{ Date } & & & & \multirow[b]{2}{*}{4} \\
\hline & & 1 & 2 & 3 & \\
\hline $\begin{array}{l}\text { Organic carbon } \\
\text { (\% dry wt) }\end{array}$ & $\begin{array}{l}\text { Jul } 97 \\
\text { Feb } 98\end{array}$ & $\begin{array}{l}2-3 \\
3-3.7\end{array}$ & $\begin{array}{r}1.8-2 \\
2-3\end{array}$ & $\begin{array}{l}1.5-2 \\
1.5-3\end{array}$ & $\begin{array}{l}0.4-0.5 \\
1-2\end{array}$ \\
\hline $\begin{array}{l}\text { Porosity } \\
\text { (ml } \mathrm{H}_{2} \mathrm{O} \mathrm{ml}{ }^{-1} \text { sediment) }\end{array}$ & $\begin{array}{l}\text { Jul } 97 \\
\text { Feb } 98\end{array}$ & $\begin{array}{l}0.75-0.92 \\
0.72-0.75\end{array}$ & $\begin{array}{l}0.76-0.82 \\
0.69-0.85\end{array}$ & $\begin{array}{l}0.65-0.80 \\
0.66-0.82\end{array}$ & $\begin{array}{l}0.55-0.68 \\
0.53-0.70\end{array}$ \\
\hline $\begin{array}{l}\text { Particles size } \\
\text { (silt/clay fraction }<65 \mu \mathrm{N}\end{array}$ & Feb 98 & $87-98 \%$ & $80-95 \%$ & $89-91 \%$ & $35-43 \%$ \\
\hline
\end{tabular}

nitrate concentration gradients in the water column from Sites 1 to 4. Nitrate concentrations in the water column were in the range 76 to $1171 \mu \mathrm{M}$ at Site 1,16 to $504 \mu \mathrm{M}$ at Site 2, and 3.3 to $94 \mu \mathrm{M}$ at Sites 3 and 4 .

At head (Site 1) of estuary. Rates of uncoupled $\left(D_{\mathrm{w}}\right)$ and coupled $\left(D_{\mathrm{n}}\right)$ denitrification in both dark and light were the highest among all sites in this

\section{Denitrification}

Varying ${ }^{15} \mathrm{NO}_{3}{ }^{-}$concentrations but keeping ${ }^{14} \mathrm{NO}_{3}^{-}$
concentration constant

Rates of $D_{14}$ (denitrification based on ${ }^{14} \mathrm{NO}_{3}{ }^{-}$) were not significantly affected by the addition of 75 to $250 \mu \mathrm{M}^{15} \mathrm{NO}_{3}^{-}$for Site 1 or 25 to $250 \mu \mathrm{M}$ for Site 4 . Thus, for the monthly measurements, usually $50 \mu \mathrm{M}$ ${ }^{15} \mathrm{NO}_{3}{ }^{-}$was used for labelling for cores from Sites 2, 3 and 4 , but $100 \mu \mathrm{M}^{15} \mathrm{NO}_{3}{ }^{-}$was used for cores from Site 1 . In certain months, when nitrate concentrations in site water were high, the added ${ }^{15} \mathrm{NO}_{3}{ }^{-}$concentration was increased accordingly to make the enrichment of ${ }^{15} \mathrm{NO}_{3}{ }^{-}$not $<30 \%$ of the unlabelled nitrate.

\section{Varying ${ }^{14} \mathrm{NO}_{3}{ }^{-}$concentrations but keeping ${ }^{15} \mathrm{NO}_{3}^{-}$concentration constant}

Rates of $D_{14}$ increased linearly with the increase of ${ }^{14} \mathrm{NO}_{3}{ }^{-}$concentration from 10 to $180 \mu \mathrm{M}$ in the water column, while rates of $D_{15}$ remained constant (Fig. 2A). This means that $D_{14}$ was independent of ${ }^{15} \mathrm{NO}_{3}{ }^{-}$and $D_{15}$ was independent of ${ }^{14} \mathrm{NO}_{3}{ }^{-}$. In other words, addition of labelled ${ }^{15} \mathrm{NO}_{3}{ }^{-}$into the water column did not kinetically affect $D_{14}$. Uncoupled denitrification $\left(D_{\mathrm{w}}\right)$ increased linearly with the ${ }^{14} \mathrm{NO}_{3}{ }^{-}$concentration in the water column, while coupled nitrification-denitrification $\left(D_{\mathrm{n}}\right)$ was constant, and unaffected by the addition of ${ }^{15} \mathrm{NO}_{3}{ }^{-}$and ${ }^{14} \mathrm{NO}_{3}{ }^{-}$to the water column (Fig. 2B). These results showed that (1) the rates of coupled nitrification-denitrification were independent of nitrate concentration in the water column, and (2) the measured rates of uncoupled denitrification were independent of ${ }^{15} \mathrm{NO}_{3}{ }^{-}$added.

\section{Results of monthly survey}

These results showed that the rates of uncoupled denitrification $\left(D_{\mathrm{w}}\right)$ decreased down the estuary to the mouth, from Sites 1 to 4 , following the decreasing estuary (average dark rates of $D_{\mathrm{w}} 530 \mu \mathrm{mol} \mathrm{N} \mathrm{m}^{-2} \mathrm{~h}^{-1}$ and $D_{\mathrm{n}} 179 \mu \mathrm{mol} \mathrm{N} \mathrm{m} \mathrm{N}^{-2} \mathrm{~h}^{-1}$, and average light rates of $D_{\mathrm{w}} 1140 \mu \mathrm{mol} \mathrm{N} \mathrm{m} \mathrm{N}^{-2}$ and $D_{\mathrm{n}} 273 \mu \mathrm{mol} \mathrm{N} \mathrm{m}{ }^{-2} \mathrm{~h}^{-1}$ from
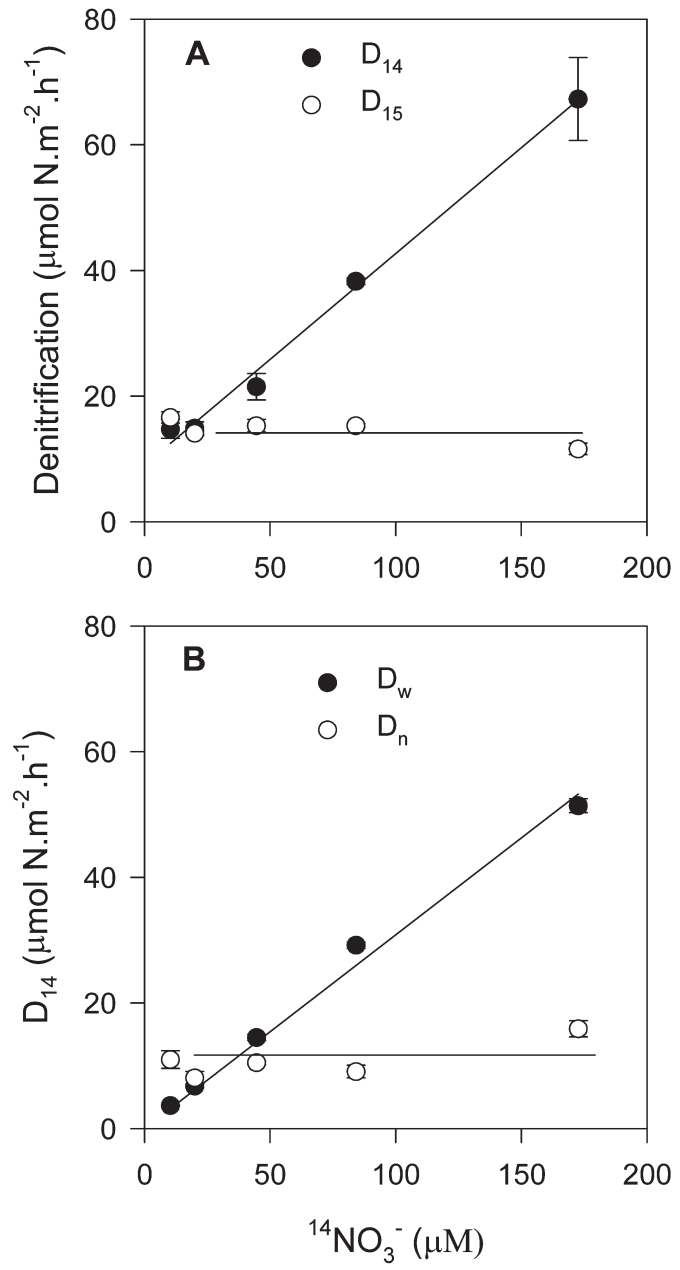

Fig. 2. Denitrification rates vs ${ }^{14} \mathrm{NO}_{3}{ }^{-}$concentration with constant $50 \mu \mathrm{M}^{15} \mathrm{NO}_{3}{ }^{-}$concentration in overlying water column for sediment at Site 4 . Incubations were at $15^{\circ} \mathrm{C}$ in darkness using artificial seawater (30\% S) on 9 December 1997. Bars indicate SE $(\mathrm{n}=4)$. (A) Rates of $D_{14}\left(D_{\mathrm{w}}+D_{\mathrm{n}}\right)$ and $D_{15}$ (denitrification based on ${ }^{15} \mathrm{NO}_{3}{ }^{-}$in water column); (B) rates of $D_{\mathrm{w}}$ (denitrification based on ${ }^{14} \mathrm{NO}_{3}{ }^{-}$in water column) and $D_{\mathrm{n}}$ (coupled nitrification-denitrification) 


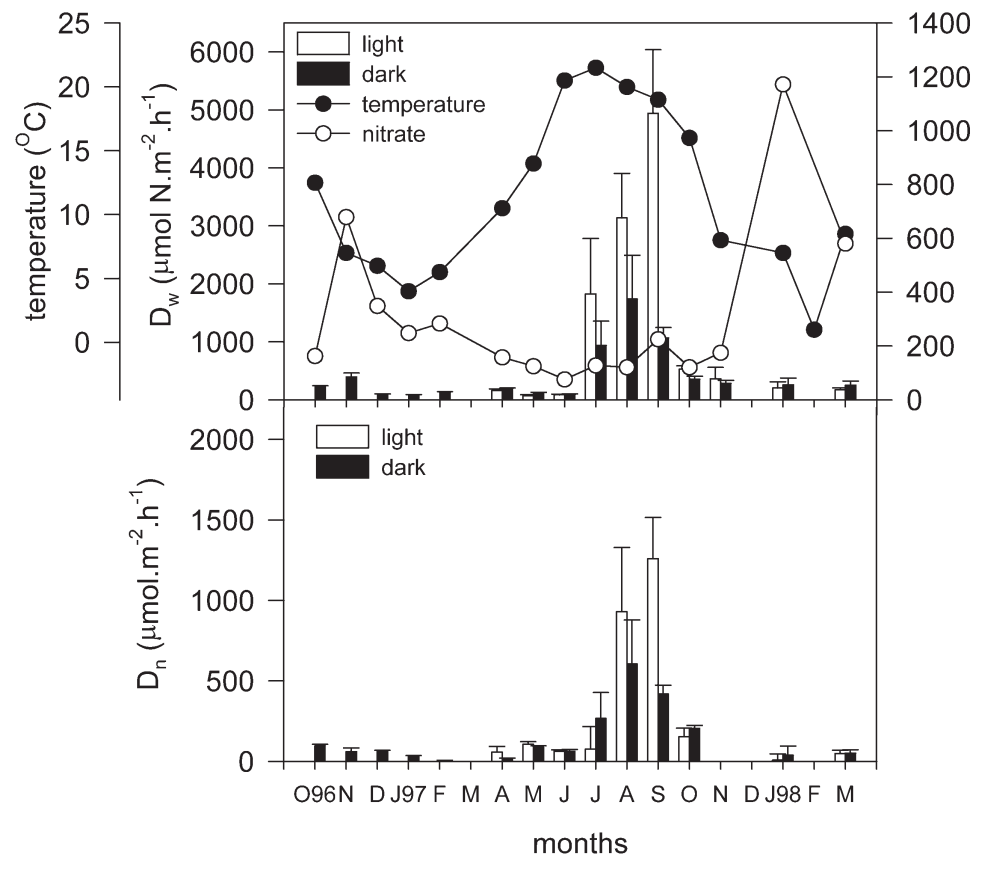

Fig. 3. Rates of uncoupled denitrification $\left(D_{\mathrm{w}}\right)$ and coupled nitrification-denitrification $\left(D_{\mathrm{n}}\right)$ in sediments measured in dark and light $\left(500 \mu \mathrm{mol} \mathrm{m} \mathrm{m}^{-2} \mathrm{~s}^{-1}\right)$ using in situ water and in situ temperature, nitrate concentration in overlying water column, and water temperature at Site 1 of River Colne estuary from

October 1996 to March 1998. Bars indicate SE $(n=5)$

April 1997 to March 1998: Fig. 3). There was a large increase in the rates of denitrification in the summer of 1997 at the same time as a significant increase in both infauna biomass and the number of individual polychaetes in the sediment (Cooper 1999). In July, August and September 1997, the rates of $D_{\mathrm{w}}$ in the light were significantly higher than those in the dark (ANOVA, p < 0.05). The reason for this is unclear. The rates of $D_{\mathrm{w}}$ measured in the light and dark for the other months were not significantly different $(\mathrm{p}>0.05)$. Rates of $D_{\mathrm{n}}$ measured in the light and dark were not significantly different from April 1997 to March 1998 ( $p$ > 0.05).

Uncoupled denitrification $\left(D_{\mathrm{w}}\right)$ represented the larger proportion (40 to $100 \%$ ) of the total denitrification, while coupled denitrification $\left(D_{\mathrm{n}}\right)$ was 0 to $60 \%$ (Fig. 4), because of the high nitrate concentration in the water column and oxygen limitation on nitrification. There was no significant difference in percentages of $D_{\mathrm{n}}$ in the dark compared with those in the light at Site 1 ( $\mathrm{p}>0.05)$.

In the middle of the estuary (Sites 2 and 3). Rates of $D_{\mathrm{w}}$ at Site 2 lay between those at Sites 1 and 4, corresponding to intermediate concentrations of nitrate (16 to $76 \mu \mathrm{M}$ ) in the water column at this site during October 1996 to November 1997. High-shore (2H) and lowshore (2L) sites showed similar rates of $D_{\mathrm{w}}$ in the dark, 15.3 to $98.2 \mu \mathrm{mol} \mathrm{N} \mathrm{m}{ }^{-2} \mathrm{~h}^{-1}$ at the high-shore (Fig. 5) and 14.3 to $64.7 \mu \mathrm{mol} \mathrm{N} \mathrm{m}^{-2} \mathrm{~h}^{-1}$ at the low-shore (data not shown) sites. In January and March 1998, nitrate concentrations in the water column were exceptionally high $(504 \mu \mathrm{M}$ in January and $227 \mu \mathrm{M}$ in March) due to the high rainfall, resulting in much higher rates of $D_{\mathrm{w}}$ at Sites $2 \mathrm{H}$ and 2L. This indicates that nitrate availability normally regulated the rate of $D_{\mathrm{w}}$. The rates of $D_{\mathrm{n}}$ in the dark at the high-shore site were not significantly different $(p>0.05)$ from those at the low-shore site, so there was no significant spatial difference in the rates of $D_{\mathrm{w}}$ or $D_{\mathrm{n}}$ at Site 2 . There was no clear seasonal pattern in the variation of $D_{\mathrm{w}}$ or $D_{\mathrm{n}}$ at Site 2.

At Site $2 \mathrm{H}$, neither $D_{\mathrm{w}}$ nor $D_{\mathrm{n}}$ in the dark were significantly different from those in the light $(\mathrm{p}>$ 0.05) (Fig. 5). The percentages of $D_{\mathrm{n}}$ in the dark and light showed no significant difference $(\mathrm{p}>$ 0.05) (Fig. 4). At Site 2L, the rates of $D_{\mathrm{n}}$ in the dark were not significantly different from those in the light ( $p>0.05)$, but the rates of $D_{\mathrm{w}}$ in the dark were significantly higher than those in the light $(\mathrm{p}<0.05)$. The percentages of $D_{\mathrm{n}}$ in the light were
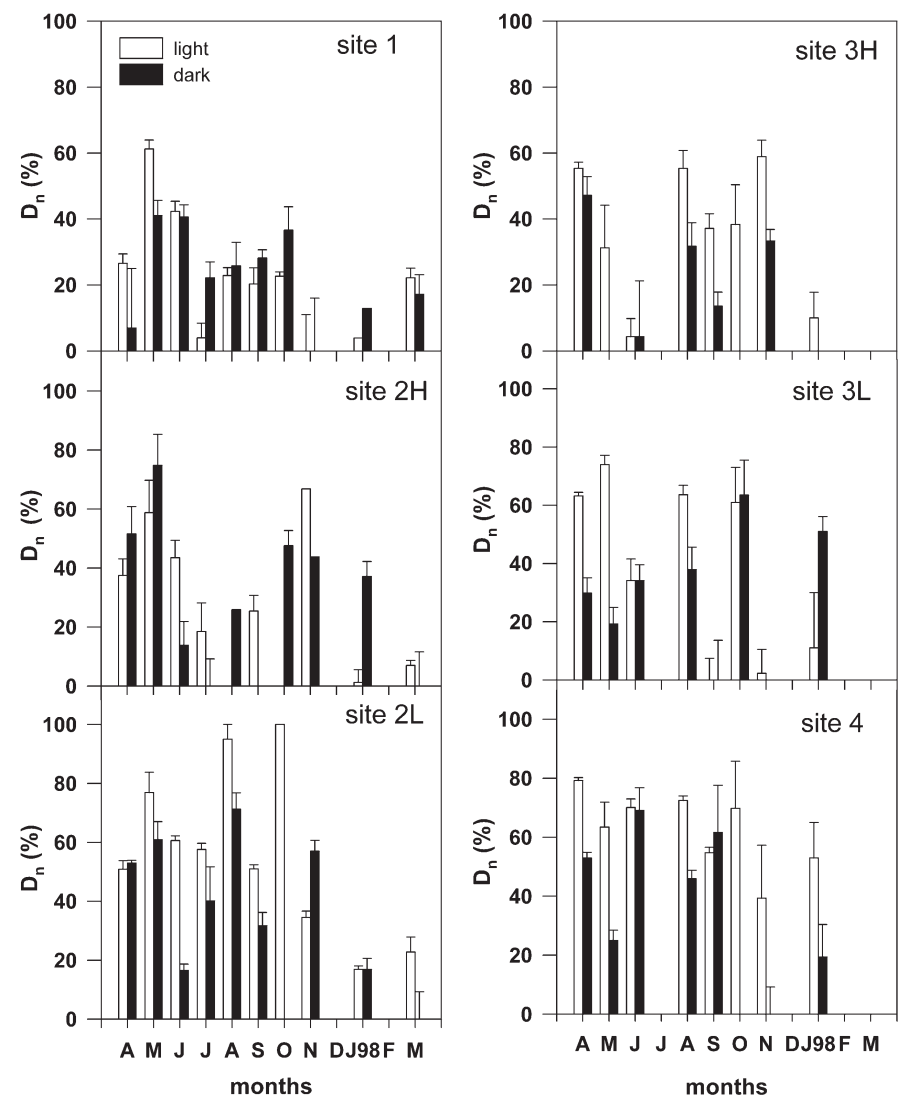

Fig. 4. Percentages of $D_{\mathrm{n}}$ in total denitrification $\left(D_{\mathrm{w}}+D_{\mathrm{n}}\right)$ at all sites of the River Colne estuary from April 1997 to March 1998. Bars indicate SE $(n=5)$. H: high shore; L: low shore 


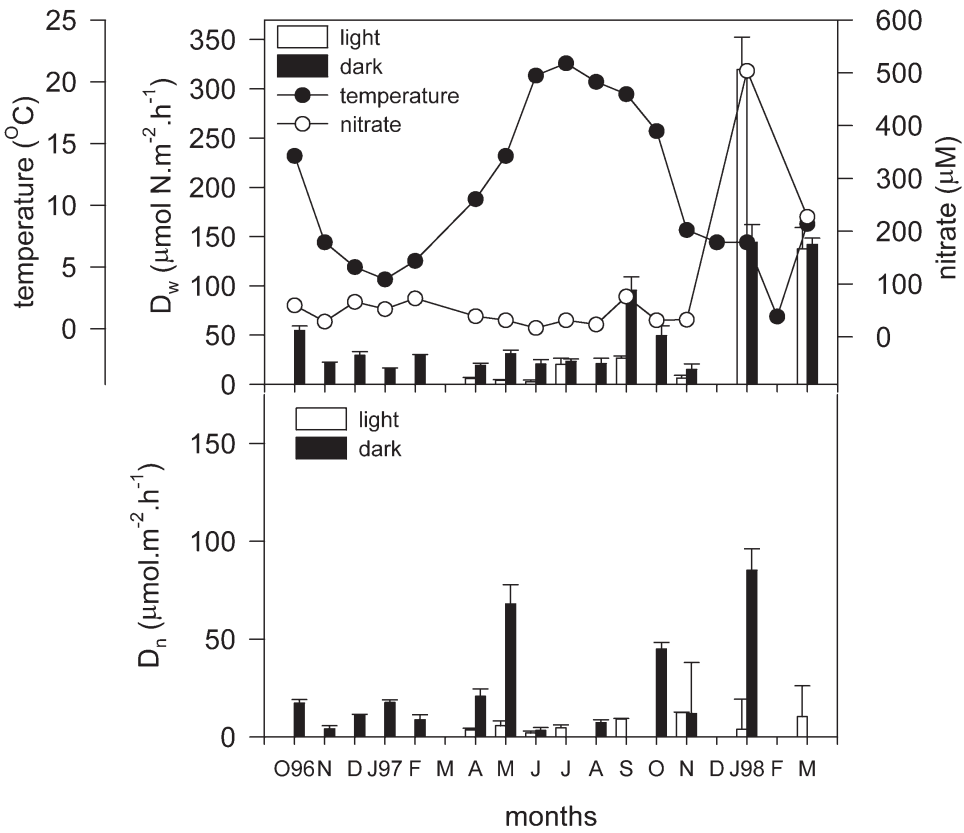

Fig. 5. Rates of uncoupled denitrification $\left(D_{\mathrm{w}}\right)$ and coupled nitrification-denitrification $\left(D_{\mathrm{n}}\right)$ in sediments measured in dark and light $\left(500 \mu \mathrm{mol} \mathrm{m} \mathrm{m}^{-2} \mathrm{~s}^{-1}\right)$ using in situ water and in situ temperature, nitrate concentration in overlying water column, and water temperature at Site $2 \mathrm{H}$ of River Colne estuary from

October 1996 to March 1998. Bars indicate SE $(n=5)$ nitrate concentrations of 3 to $38 \mu \mathrm{M}$ in the overlying water (Fig. 7). However, in January 1998, due to high rainfall, nitrate concentrations in the water column rose to $94 \mu \mathrm{M}$. Correspondingly, the rates of denitrification increased up to $69.5 \mu \mathrm{mol} \mathrm{N} \mathrm{m}^{-2}$ $\mathrm{h}^{-1}$ in the dark and $23.3 \mu \mathrm{mol} \mathrm{N} \mathrm{m}^{-2} \mathrm{~h}^{-1}$ in the light. This suggested that nitrate availability in the water column was limiting the rate of $D_{\mathrm{w}}$ at Site 4. Further evidence that water-column nitrate limited the rate of benthic denitrification at Site 4 was supplied by the nitrate supplementation experiment. A linear relationship between $D_{\mathrm{w}}$ and nitrate concentration in the overlying water was observed up to nitrate concentrations of $180 \mu \mathrm{M}$ in dark incubation (Fig. 2) at this site.

From April 1997 to January 1998, the rates of $D_{\mathrm{w}}$ in the dark and light were not significantly different ( $\mathrm{p}>0.05)$, but the rates of $D_{\mathrm{n}}$ in the light were significantly higher than those in the dark ( $p<$ 0.05), suggesting that oxygen produced by the biofilms may stimulate $D_{\mathrm{n}}$ via enhanced nitrification. In most months, the percentages of $D_{\mathrm{n}}$ were significantly higher in the light than in the dark $(p<0.05)$. The coupled denitrification at this site represented a larger proportion of the total denitrification (25 to $80 \%$ ) than at Site 1 (Fig. 4). significantly higher than in the dark $(\mathrm{p}<0.05)$ (Fig. 4). This suggests that oxygen produced by the benthic biofilms in the light may inhibit $D_{\mathrm{w}}$ at Site 2L.

At Site 3 , the rates of $D_{\mathrm{w}}$ in the dark at both high-shore and low-shore were similar $(\mathrm{p}>0.05$ : average 10.2 , range 1.9 to $23.5 \mu \mathrm{mol} \mathrm{N} \mathrm{m}{ }^{-2} \mathrm{~h}^{-1}$, at high-shore [Fig. 6] site and average 9.4, range 1.1 to $28 \mu \mathrm{mol} \mathrm{N} \mathrm{m} \mathrm{N}^{-2} \mathrm{~h}^{-1}$ at low shore site [data not shown]). The rates of $D_{\mathrm{n}}$ in the dark at highshore (average 2.4, range 0 to $6.6 \mu \mathrm{mol} \mathrm{N} \mathrm{m} \mathrm{N}^{-2} \mathrm{~h}^{-1}$ ) site were significantly lower $(p>0.05)$ than at low-shore (average 6, range 0 to $15.7 \mu \mathrm{mol} \mathrm{N} \mathrm{m}^{-2}$ $\mathrm{h}^{-1}$ ) site. Neither $D_{\mathrm{w}}$ nor $D_{\mathrm{n}}$ in the light at highshore or low-shore sites was significantly different ( $p>0.05$ ). The percentages of $D_{n}$ at both highshore and low-shore sites were significantly higher in the light than in the dark ( $p<0.05$, Fig. 4). There was no clear seasonal pattern in the variation of $D_{\mathrm{w}}$ or $D_{\mathrm{n}}$ at Site 3.

At the mouth (Site 4) of the estuary. Rates of $D_{\mathrm{w}}$ were the lowest among all sites in the estuary, in the ranges 1.2 to $13.1 \mu \mathrm{mol} \mathrm{N} \mathrm{m} \mathrm{N}^{-2} \mathrm{~h}^{-1}$ in the dark (October 1996 to November 1997) and 1.4 to $13.9 \mu \mathrm{mol} \mathrm{N} \mathrm{m}^{-2} \mathrm{~h}^{-1}$ in the light (April 1997 to November 1997), corresponding to the lowest

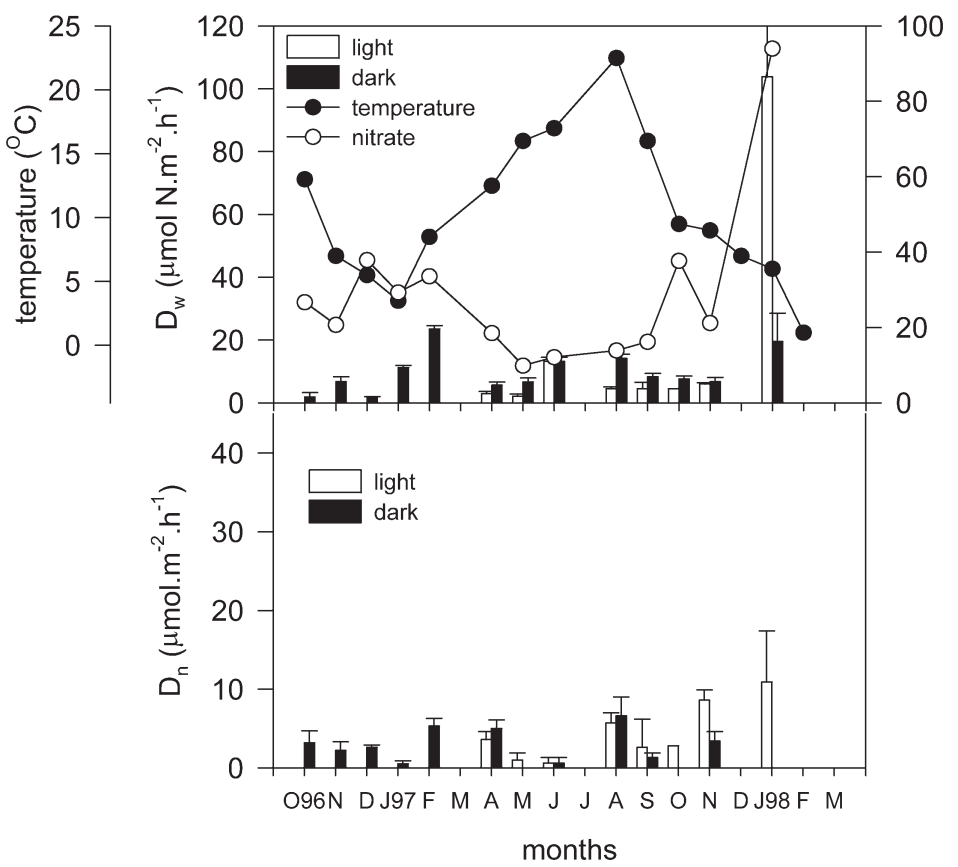

Fig. 6. Rates of uncoupled denitrification $\left(D_{\mathrm{w}}\right)$ and coupled nitrification-denitrification $\left(D_{\mathrm{n}}\right)$ in sediments measured in dark and light $\left(500 \mu \mathrm{mol} \mathrm{m} \mathrm{m}^{-2} \mathrm{~s}^{-1}\right)$ using in situ water and in situ temperature, nitrate concentration in overlying water column, and water temperature at Site $3 \mathrm{H}$ of River Colne estuary from October 1996 to March 1998. Bars indicate SE $(n=5)$ 


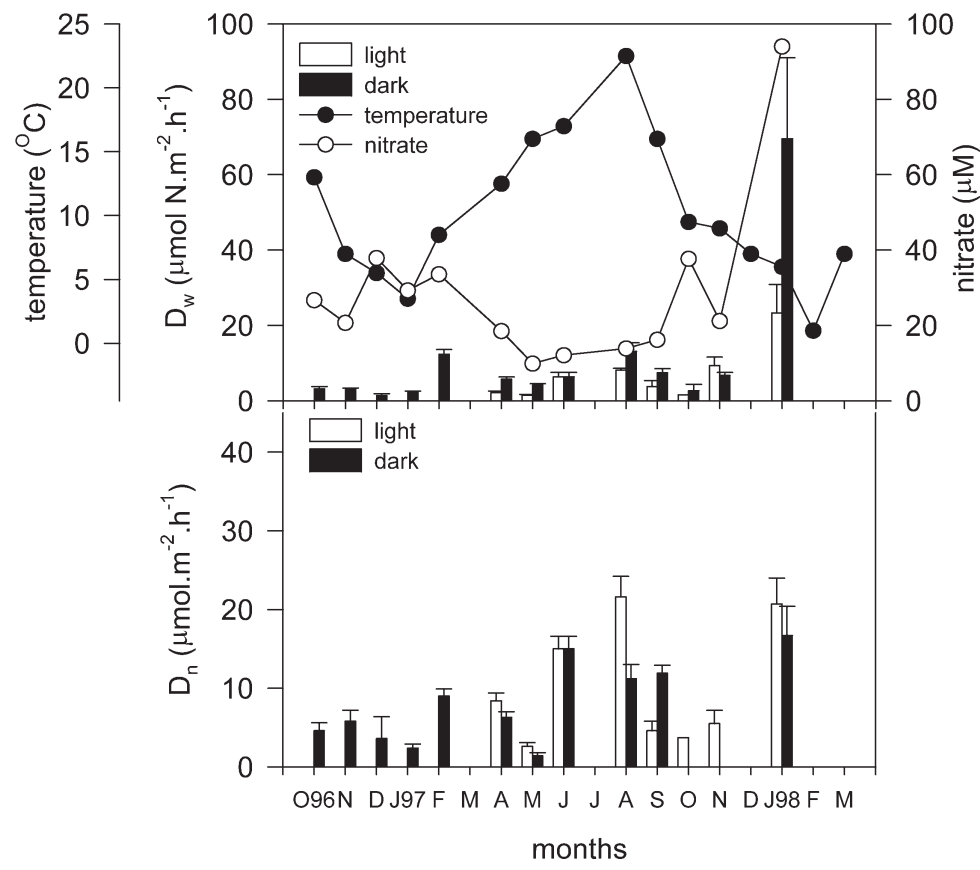

Fig. 7. Rates of uncoupled denitrification $\left(D_{\mathrm{w}}\right)$ and coupled nitrification-denitrification $\left(D_{\mathrm{n}}\right)$ in sediments measured in dark and light $\left(500 \mu \mathrm{mol} \mathrm{m} \mathrm{m}^{-2} \mathrm{~s}^{-1}\right)$ using in situ water and in situ temperature, nitrate concentration in overlying water column, and water temperature at Site 4 of River Colne estuary from

October 1996 to March 1998. Bars indicate SE $(n=5)$

\section{Oxygen fluxes across sediment/water interface}

At Site 1, there was a net uptake of oxygen by the sediment both in the dark and light during most months, but a net output of oxygen in the light on 4 occasions (Fig. 8). Oxygen uptake rates by the sediment were linearly correlated to the water temperature in the dark $\left(\mathrm{r}^{2}=0.80\right)$.

At Sites 2, 3 and 4, there were generally net oxygen fluxes from the sediment into the overlying water in the light, arising from the photosynthesis of the diatom-dominated benthic biofilms on the surface of the sediment, and net oxygen uptake in the dark (Fig. 8). There were no clear seasonal patterns in the rates of oxygen flux at Sites 2, 3 and 4.

\section{Short-term kinetic experiments on effect of microphytobenthic biofilms on denitrification}

At Site 1, the chlorophyll a content in the top $50 \mathrm{~mm}$ layer of the sediment samples (collected in April 1998) was $29.9 \pm 3.3 \mu \mathrm{g} \mathrm{g}^{-1}$ dry sediment (mean $\pm \mathrm{SE}, \mathrm{n}=5$ ) . The net $\mathrm{O}_{2}$ output by the diatom-dominated biofilms was $4 \mathrm{mmol} \mathrm{O}_{2} \mathrm{~m}^{-2} \mathrm{~h}^{-1}$ in the light, and the net $\mathrm{O}_{2}$ uptake by the sediment was $7.2 \mathrm{mmol} \mathrm{O}_{2} \mathrm{~m}^{-2} \mathrm{~h}^{-1}$ in the dark. The rates of $D_{\mathrm{w}}$ increased linearly with increasing nitrate concentration in the water column (Fig. 9A). The slopes of the linear regression of the rates of $D_{\mathrm{w}}$ versus nitrate concentrations showed no significant difference in the light and dark ( $\mathrm{p}>$ 0.05). The measured rates of $D_{\mathrm{n}}$ (Fig. 9B) in the light $(126.6 \pm 17.8, n=20)$ were significantly higher than in the dark $(18.8 \pm 6.7, \mathrm{n}=20)(\mathrm{p}<0.05)$, but unaffected by $\mathrm{NO}_{3}{ }^{-}$concentration. This means that the $D_{\mathrm{n}}$ was stimulated but the $D_{\mathrm{w}}$ unaffected by $\mathrm{O}_{2}$ produced by diatoms in the light at this site. The results also show that there was a big potential in denitrification at this site, since even up to a concentration of $600 \mu \mathrm{M}$ nitrate the rates of $D_{\mathrm{w}}$ were still not saturated.

At Site $2 \mathrm{H}$, the chlorophyll a content in the top $50 \mathrm{~mm}$ layer of sediment samples (collected in July 1998) was $50.2 \pm 3.6 \mu \mathrm{g} \mathrm{g}^{-1}$ dry sediment (mean $\pm \mathrm{SE}, \mathrm{n}=5$ ). High rates of net oxygen output (8.1 mmol $\mathrm{O}_{2} \mathrm{~m}^{-2} \mathrm{~h}^{-1}$ ) were observed in the light arising from the photosynthesis of the benthic biofilms, but net oxygen uptake $\left(2.45 \mathrm{mmol} \mathrm{O} \mathrm{m}^{-2}\right.$ $\mathrm{h}^{-1}$ ) by the sediment was measured in the dark. The rates of $D_{\mathrm{w}}$ responded to changes in nitrate con-
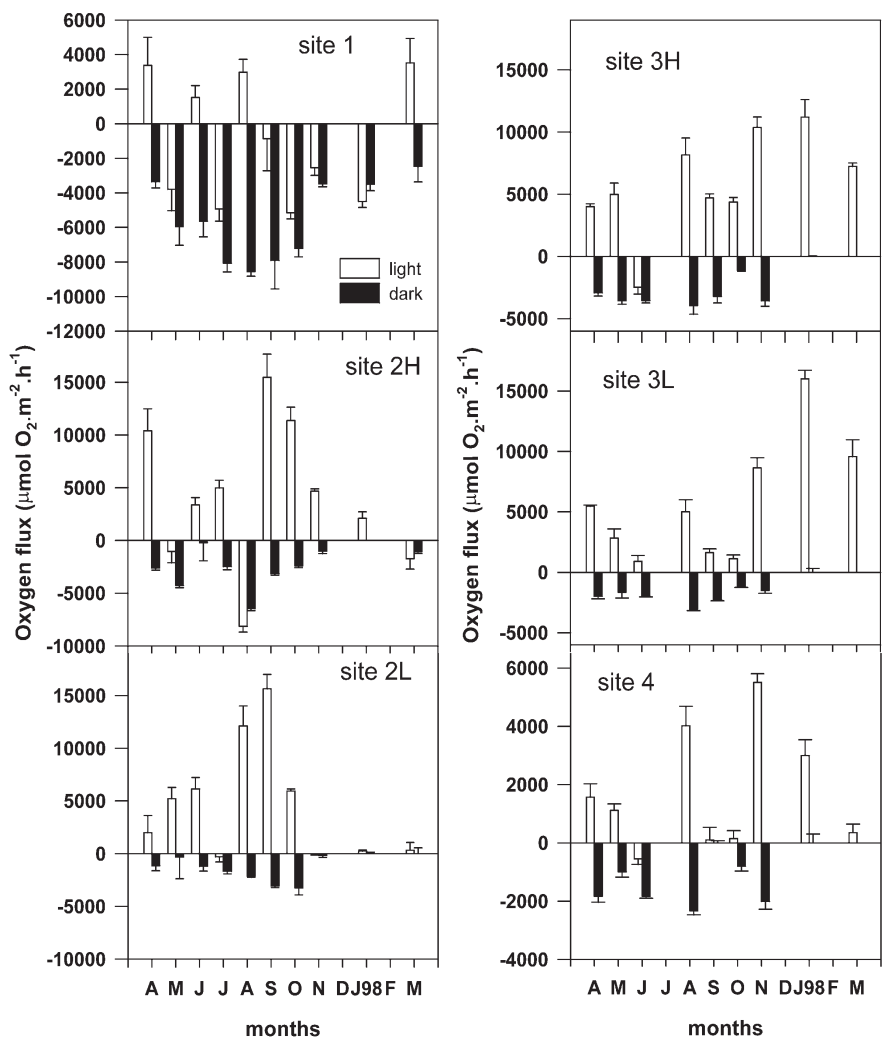

Fig. 8. Rates of oxygen flux across sediment/water interface measured in dark and light $\left(500 \mu \mathrm{mol} \mathrm{m} \mathrm{m}^{-2} \mathrm{~s}^{-1}\right)$ using in situ water and in situ temperature at all sites of River Colne estuary from April 1997 to March 1998. Bars indicate SE $(n=3)$ 

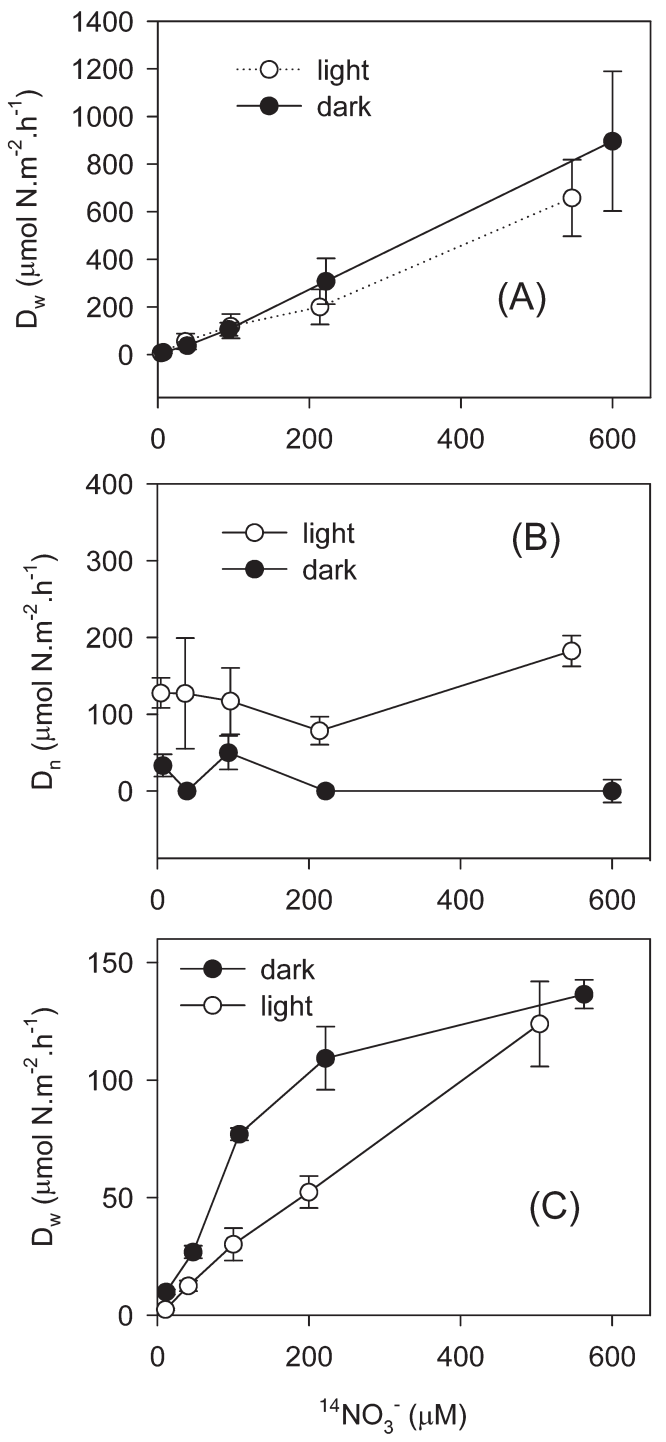

Fig. 9. Rates of $D_{\mathrm{w}}$ and $D_{\mathrm{n}} \mathrm{vs}{ }^{14} \mathrm{NO}_{3}{ }^{-}$concentration with constant $110 \mu \mathrm{M}^{15} \mathrm{NO}_{3}{ }^{-}$concentration in water column for sediments at Sites 1 and $2 \mathrm{H}$ of River Colne estuary. Incubations were at $15^{\circ} \mathrm{C}$ in dark and light $\left(500 \mu \mathrm{mol} \mathrm{m}^{-2} \mathrm{~s}^{-1}\right)$ using artificial seawater $(15 \%$ S) on 29 April 1998 for Site 1 and 29 July 1998 for Site $2 H$. Bars indicate SE $(\mathrm{n}=4)$. (A) Rates of $D_{\mathrm{w}}$ for Site $1 ;$ (B) rates of $D_{\mathrm{n}}$ for Site 1 ; and (C) rates of $D_{\mathrm{w}}$ for Site $2 \mathrm{H}$

centrations, with typical Michaelis-Menten-type saturation kinetics in the dark, but first-order kinetics in the light (Fig. 9C). Below $500 \mu \mathrm{M}$ nitrate, the rate of $D_{\mathrm{w}}$ in the dark was significantly higher than in the light $(\mathrm{p}<0.05)$. At $500 \mu \mathrm{M}$ nitrate, the rates of $D_{\mathrm{w}}$ in the dark and light became similar. The rates of $D_{\mathrm{n}}$ in the dark were not significantly $(p>0.05)$ different from those in the light, and were not affected by increase of nitrate concentration in the water column (data not shown). The results indicate that at Site $2 \mathrm{H}$ the effect of benthic biofilms on denitrification was to inhibit $D_{\mathrm{w}}$.
At Site $2 \mathrm{H}$, kinetic experiments also show that the rates of denitrification seemed not to be saturated under $500 \mu \mathrm{M}$ (Fig. 10). The Eadie-Hofstee-transformed version of the Michaelis-Menten equation $\left(\left[\mathrm{NO}_{3}{ }^{-}\right] / D_{14}=\left[\mathrm{NO}_{3}{ }^{-}\right] / D_{\max }+K_{\mathrm{m}} / D_{\max }\right.$, Day et al. 1989) was used to deduce the maximum rate of denitrification $\left(D_{\max }=222 \mu \mathrm{mol} \mathrm{N} \mathrm{m}{ }^{-2} \mathrm{~h}^{-1}\right)$ and the half-saturation concentration of nitrate $\left(K_{\mathrm{m}}=187.8 \mu \mathrm{M}\right)$ in the dark. This further demonstrated that there was a large potential for denitrification at this site, and the rates were usually limited by low availability of nitrate throughout the year because the nitrate concentrations in site water were usually below the $K_{\mathrm{m}}$ (Fig. 10).

\section{DISCUSSION}

\section{Isotope-pairing technique for denitrification measurements}

The isotope-pairing technique (Nielsen 1992) for denitrification measurements allows quantification of both coupled nitrification-denitrification $\left(D_{\mathrm{n}}\right)$ and uncoupled denitrification supported by nitrate diffusing into the sediment from the overlaying water column $\left(D_{\mathrm{w}}\right)$. However, correct measurement of denitrification by this technique requires fulfilment of 4 assumptions: namely that the added ${ }^{15} \mathrm{NO}_{3}{ }^{-}$must mix homogeneously with the ${ }^{14} \mathrm{NO}_{3}{ }^{-}$in the water column and in the sediment; the addition of ${ }^{15} \mathrm{NO}_{3}{ }^{-}$must not alter the in situ

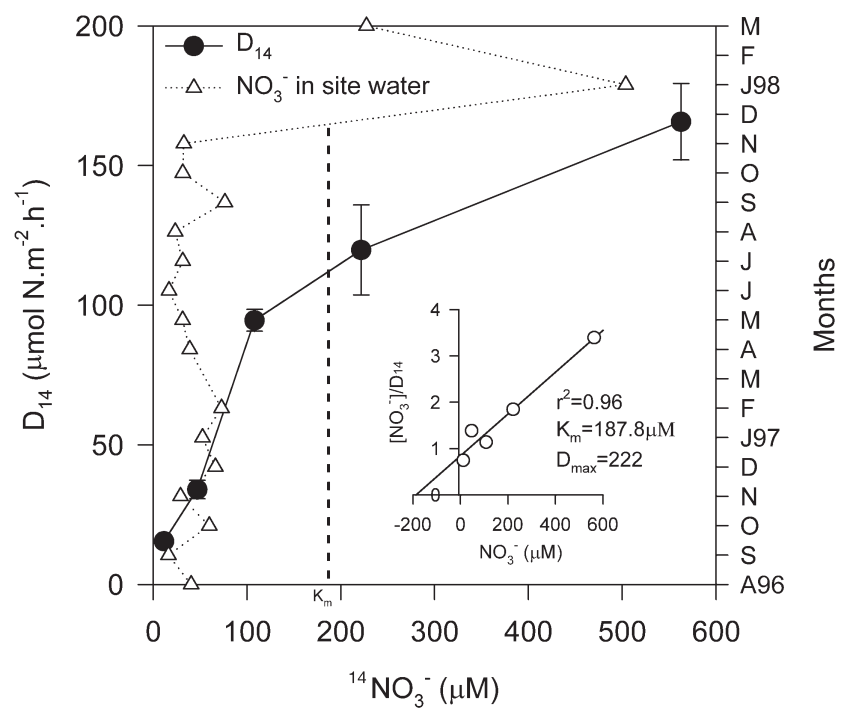

Fig. 10. Rates of denitrification vs ${ }^{14} \mathrm{NO}_{3}{ }^{-}$concentration with constant $110 \mu \mathrm{M}^{15} \mathrm{NO}_{3}^{-}$concentration in overlying water column for sediment at Site $2 \mathrm{H}$. Incubations were at $15^{\circ} \mathrm{C}$ in darkness using artificial seawater (15\% S) on 19 February 1997, and nitrate concentrations of in situ water from August 1996 to March 1998. Bars indicate SE $(\mathrm{n}=4)$ 
rates of coupled and uncoupled denitrification; the isotope fractionation can be neglected; and the 2 isotopes $\left({ }^{14} \mathrm{NO}_{3}{ }^{-}\right.$and $\left.{ }^{15} \mathrm{NO}_{3}{ }^{-}\right)$diffuse similarly, i.e. according to their abundance ratio.

Kinetic experiments (Fig. 2A) demonstrated that the rates of $D_{15}$ were constant even with increasing ${ }^{14} \mathrm{NO}_{3}{ }^{-}$ concentration in the water column and the ratios of ${ }^{14} \mathrm{~N}^{15} \mathrm{~N}$ to ${ }^{15} \mathrm{~N}^{15} \mathrm{~N}$ increased linearly with increase of ${ }^{14} \mathrm{NO}_{3}{ }^{-}$concentration, thus verifying the assumption of homogeneous mixture of added ${ }^{15} \mathrm{NO}_{3}{ }^{-}$with ${ }^{14} \mathrm{NO}_{3}{ }^{-}$. The added ${ }^{15} \mathrm{NO}_{3}{ }^{-}$equilibrated rapidly with ${ }^{14} \mathrm{NO}_{3}{ }^{-}$, in only 30 to $40 \mathrm{~min}$. Several authors (Broast et al. 1988, Nielsen 1992, Pelegri et al. 1994, Risgaard et al. 1994, Rysgaard et al. 1995) have demonstrated that when the production of ${ }^{14} \mathrm{~N}^{15} \mathrm{~N}$ was less than that predicted on the assumption of homogeneity, the in situ denitrification could be underestimated.

There was a first-order kinetic relationship between the rates of $D_{\mathrm{w}}$ and the ${ }^{14} \mathrm{NO}_{3}{ }^{-}$concentrations in the water column when a constant $50 \mu \mathrm{M}{ }^{15} \mathrm{NO}_{3}{ }^{-}$was added at Site 4 (Fig. 2B) and $110 \mu \mathrm{M}{ }^{15} \mathrm{NO}_{3}{ }^{-}$added at Site 1 (Fig. 9A). The rates of $D_{\mathrm{n}}$ were independent of ${ }^{14} \mathrm{NO}_{3}{ }^{-}$concentrations in the water column with $50 \mu \mathrm{M}$ ${ }^{15} \mathrm{NO}_{3}{ }^{-}$added at Site 4 (Fig. 2B) and with $110 \mu \mathrm{M}$ ${ }^{15} \mathrm{NO}_{3}{ }^{-}$added at Site 1 (Fig. 9B). These results indicate that addition of ${ }^{15} \mathrm{NO}_{3}{ }^{-}$affected neither $D_{\mathrm{w}}$ (based on in situ ${ }^{14} \mathrm{NO}_{3}{ }^{-}$) nor $D_{\mathrm{n}}$. The second assumption was thus satisfied.

Discrimination against ${ }^{15} \mathrm{~N}$ in the process of denitrification was reported to result in an error $<0.5 \%$, and can therefore be disregarded (Middelburg et al. 1996). The validity of the 4 th assumption that the 2 isotopes $\left({ }^{14} \mathrm{NO}_{3}\right.$ and $\left.{ }^{15} \mathrm{NO}_{3}\right)$ diffuse similarly has generally been accepted by the users of the isotope-pairing technique, although it has been questioned in some circumstances (Middelburg et al. 1996).

\section{Field and laboratory work}

The rates of $D_{\mathrm{w}}$ decreased from Sites 1 to 4 , following the $\mathrm{NO}_{3}{ }^{-}$concentrations in the water column. At Site 1, where the nitrate concentrations were the highest among all sites in this estuary, the rates of $D_{\mathrm{w}}$ were also the highest, but not correlated to the nitrate concentrations in the water column (Fig. 3). For example, in the summer of 1997, the rates of $D_{\mathrm{w}}$ were significantly higher than other months $(p<0.05)$, although the nitrate concentrations in the water column were lower than in the winter. It is likely that the increase in the rates of denitrification at this time was due to the increased activities of the benthic infauna through burrow building, bioturbation and irrigation (Rhoads 1974, Aller 1982, Kristensen 1984, Pelegri et al. 1994, Cooper 1999). However, at Sites 2, 3 and 4, the rates of
$D_{\mathrm{w}}$ responded to the changes in nitrate concentrations in the water column with typical Michaelis-Menten kinetics from October 1996 to March 1998 (Fig. 11). The nitrate concentrations in the water column at Site 2 were usually below the $K_{\mathrm{m}}\left(187.8 \mu \mathrm{M}_{\text {; Fig. }} 10\right)$ and were even lower at Sites 3 and 4 (Figs. $6 \&$ 7). These data indicate that in most of the estuary (Sites 2, 3, and 4) availability of nitrate limited the rates of $D_{\mathrm{w}}$ but not at Site 1.

It must be emphasized that denitrification is not only determined by nitrate concentration in the water column, but also by organic carbon content in the sediment. The present study showed that at a concentration of nitrate below the saturation concentration, the rates of $D_{\mathrm{w}}$ were different at a given nitrate concentration (for instance, $100 \mu \mathrm{M} \mathrm{NO}_{3}{ }^{-}$) at different sites (100 $\mu \mathrm{mol} \mathrm{N} \mathrm{m}{ }^{-2} \mathrm{~h}^{-1}$ at Site 1 (Fig. 9A), $70 \mu \mathrm{mol} \mathrm{N} \mathrm{m}{ }^{-2}$ $\mathrm{h}^{-1}$ at Site 2 (Fig. 9C), and $30 \mu \mathrm{mol} \mathrm{N} \mathrm{m}{ }^{-2} \mathrm{~h}^{-1}$ at Site 4 (Fig. 2B), possibly in relation to the different organic carbon contents in these 3 sediments. This suggests that organic carbon content of the sediment may determine the potential capacity of bacterial denitrification. However, the potential can be tapped only when nitrate concentration in the water column is not limiting. The implication of the high potential capacity of denitrification in the Colne estuary is that nitrate removal by denitrification could increase with nitrate loading of the estuary up to the saturation concentrations of nitrate.

In addition to stimulating the rate of denitrification, nitrate availability has also been found to influence the end-products of nitrate dissimilation by bacteria (King \& Nedwell 1985), and to affect the adaptation of nitrate-reducing bacterial communities in estuarine sedi-

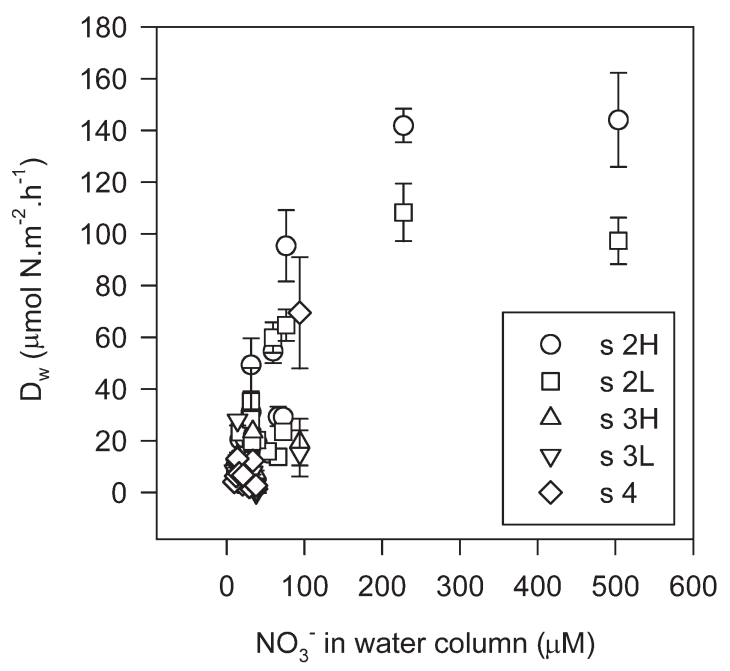

Fig. 11. Rates of $D_{\mathrm{w}}$ in darkness vs in situ overlying estuarine nitrate concentrations at Sites 2, 3 and 4 of River Colne estuary from October 1996 to March 1998. Bars indicate SE (n = 5) 
ments (King \& Nedwell 1987). As nitrate concentration increased, the proportion of the nitrate which was denitrified increased, while the proportion of nitrate which was reduced to ammonium correspondingly decreased (King \& Nedwell 1985). Bacterial communities in those sediments having greater nitrate concentrations exhibited faster rates of nitrate reduction (King \& Nedwell 1987). This adaptation probably explains the higher potential rates of denitrification by sediments at Sites 1 and 2 than at Site 4 .

The half saturation concentration of nitrate $\left(K_{\mathrm{m}}=\right.$ $187.8 \mu \mathrm{M})$ at Site 2 was not a real reflection of the affinity of denitrifying bacteria for nitrate, but an overall reflection of the 'affinity' of the sediments for nitrate. This includes overall affinity from different populations of denitrifying bacteria within the sediment, the depth of oxygen penetration in the surface layer of the sediment, the grain size of the sediment etc. Denitrifying bacteria have a high affinity for nitrate, as $K_{\mathrm{m}}$ values are commonly 10 to $50 \mu \mathrm{M}$ (Billen 1978, Koike \& Hattori 1978). A recent study (Garcia-Ruiz et al. 1998) showed that $K_{\mathrm{m}}$ increased on passing downstream from 13.1 to $90.4 \mu \mathrm{M}$ in the Swale-Ouse river system in northeastern England.

In addition to assimilating inorganic nitrogen, the microphytobenthic biofilms also affected the rates of uncoupled and coupled denitrification. At the low shore of Site 2, the rates of $D_{\mathrm{w}}$ were significantly lower in the light (annual average $31.5 \mu \mathrm{mol} \mathrm{N} \mathrm{m} \mathrm{N}^{-2} \mathrm{~h}^{-1}$ ) than in the dark $\left(44.4 \mu \mathrm{mol} \mathrm{N} \mathrm{m} \mathrm{N}^{-2} \mathrm{~h}^{-1}\right)(\mathrm{p}<0.05)$, but at other sites the rates of $D_{\mathrm{w}}$ in the light were not significantly different from those in the dark.

Among all sites in this estuary, only at Site 4 were the rates of $D_{\mathrm{n}}$ in the light (annual average $11.3 \mu \mathrm{mol} \mathrm{N} \mathrm{m} \mathrm{N}^{-2}$ $\left.\mathrm{h}^{-1}\right)$ significantly higher that those in the dark $(7.8 \mu \mathrm{mol}$ $\left.\mathrm{N} \mathrm{m}^{-2} \mathrm{~h}^{-1}\right)(\mathrm{p}<0.05)$. However, at most sites $(2 \mathrm{~L}, 3 \mathrm{H}$, $3 \mathrm{~L}, 4)$ the percentages of $D_{\mathrm{n}}$ in the total denitrification $\left(D_{\mathrm{w}}+D_{\mathrm{n}}\right)$ were significantly higher $(\mathrm{p}<0.05)$ in the light than in the dark (annual average percentages of $D_{\text {n }}$ were 56 and $34.7 \%$ in the light and dark at Site 2L; 36.3 and $16.3 \%$ at Site $3 \mathrm{H}_{;} 38.7$ and $29.4 \%$ at Site 3L; and 62.7 and $34.2 \%$ at Site 4 ). This suggests that oxygen production by the diatom biofilms reduced denitrification activity based on nitrate supply from the water column $\left(D_{\mathrm{w}}\right)$, probably by increasing the depth of oxic layer on the surface of the sediment and consequently increasing the diffusion path length, but stimulated coupled nitrification-denitrification $\left(D_{\mathrm{n}}\right)$. The overall effect was to increase the percentage of $D_{\mathrm{n}}$ in the total denitrification.

This conclusion was supported by the results of the short-term kinetic experiments. At Site 1, the rates of $D_{n}$ were significantly stimulated by the $\mathrm{O}_{2}$ produced by the biofilms (Fig. 9B), while at Site $2 \mathrm{H}$ the rates of $D_{\mathrm{w}}$ were significantly reduced by the $\mathrm{O}_{2}$ produced by the biofilms (Fig. 9C). At Site 1, although the artificial seawater used for the kinetic experiment was ammoniumfree, the ammonium concentration in the pore water of the sediment was very high (2 to $3 \mathrm{mM})$; so for nitrification in the sediment availability of ammonium was unlikely to have been rate-limiting. In this case, any increase in $\mathrm{O}_{2}$ concentration in the nitrification zone would increase nitrification, and consequently the activity of coupled denitrification. At Site $2 \mathrm{H}$, the lower rates of $D_{\mathrm{w}}$ in the light than in the dark were most probably due to the inhibition of $\mathrm{O}_{2}$ produced by the diatoms. Chlorophyll a content in the sediment and net $\mathrm{O}_{2}$ output in the light were 1.7 times and 2 times those at Site 1, respectively. After $15 \mathrm{~min}$ illumination at $500 \mu \mathrm{mol} \mathrm{m}{ }^{-2} \mathrm{~s}^{-1}$, the $\mathrm{O}_{2}$ concentration in the top $20 \mathrm{~mm}$ of the sediment rose to 2.3 times that of the dark control (this was measured by the oxygen microelectrode mentioned in 'Materials and methods'). The penetration of $\mathrm{O}_{2}$ further down into the sediment increased the diffusion-path length for nitrate from the water column into the denitrifying zone, thereby retarding $D_{\mathrm{w}}$. The rates of $D_{\mathrm{n}}$ in the dark and light were not significantly different, although high rates of net oxygen output were observed in the light. This suggests that, in the light, nitrification in the sediment at Site $2 \mathrm{H}$ would be ammonium-limited, but no definite conclusion can be reached in this regard since the pore-water ammonium concentration was not measured.

It should be mentioned here that there were variations in the measurement of denitrification between replicates. This was mainly due to the heterogeneity of the sediment samples, the sampling procedure for slurry after incubation, and the measurement of the gas sample by the mass spectrometer. The observed variations were in fact caused by a combination of these 3 factors.

\section{Budgets}

By multiplying the measured rates of uncoupled denitrification $\left(D_{\mathrm{w}}\right)$ (using the mean rates of high and low shores at Sites 2 and 3) at each site and in each month (from April 1997 to March 1998) by the total area of sediment (which is defined as the area totally immersed at spring tide) in the sector of the river centred around that site, the total $D_{\mathrm{w}}$ for the Colne estuary was estimated to be $6.57 \mathrm{Mmol} \mathrm{N}$ per year (for each month, the equation $=\left[\right.$ dark $D_{\mathrm{w}} \times 18 \mathrm{~h}+$ light $\left.D_{\mathrm{w}} \times 6 \mathrm{~h}\right] \times$ area $\times$ $365 / 12$ ). The total annual fluxes of oxidized nitrogen $(\mathrm{TOxN})$ into the estuary from both the river and the inputs of the sewage-treatment works was $14.76 \mathrm{Mmol}$ $\mathrm{N}$ in 1996, calculated by multiplying nitrate and nitrite concentrations by freshwater flow-rate and by time. Nutrient concentrations were measured weekly, and 
freshwater flow-rates were measured daily by the Environment Agency of the UK (the authority organisation in the UK). Thus, uncoupled denitrification supported by nitrate from the water column in the estuary was equivalent to $44.5 \%$ of the annual flux of total oxidised nitrogen (mainly nitrate). Because the turnover of the nitrate pool in the sediment was rapid, and the sediment nitrate pool was depleted relatively quickly after exposure by the tide, a more conservative estimate of the $D_{\mathrm{w}}$ in this estuary could be made by multiplying the rates of denitrification in each sector by the area of tidally immersed sediment in that sector, which was equivalent to about $72 \%$ of the total estuarine sedimentary area (Ogilvie et al. 1997). This gave an annual estimate of uncoupled denitrification of $4.73 \mathrm{Mmol} \mathrm{N}$ $\mathrm{yr}^{-1}$, which attenuated $32 \%$ of the annual flux of total oxidised nitrogen. These estimates are very close to those of a previous study (Ogilvie et al. 1997), and indicate interannual comparability in denitrification in the Colne estuary.

Although a significant amount of TOxN can be removed from the water column of the estuary only through $D_{\mathrm{w}}$ coupled nitrification-denitrification $\left(D_{\mathrm{n}}\right)$ also plays an important role in removal of nitrate produced via nitrification in the sediment of the estuarine. The estimated amounts of nitrogen removed by $D_{\mathrm{n}}$ were obtained by multiplying the measured rates of $D_{\mathrm{n}}$ at each site in each month (from April 1997 to March 1998) by the total sediment area in each sector (for each month, equation $=\left[\operatorname{dark} D_{\mathrm{n}} \times 18 \mathrm{~h}+\operatorname{light} D_{\mathrm{n}} \times 6 \mathrm{~h}\right]$ $\times$ area $\times 365 / 12$ ). This was $2.2 \mathrm{Mmol} \mathrm{N} \mathrm{yr}^{-1}$, which was one-third of the amount of $\mathrm{N}$ removed by $D_{\mathrm{w}}$.

The total denitrification $\left(D_{\mathrm{w}}+D_{\mathrm{n}}\right.$, or $\left.72 \% D_{\mathrm{w}}+D_{\mathrm{n}}\right)$ of 8.77 (or 6.93) $\mathrm{Mmol} \mathrm{N} \mathrm{yr}^{-1}$ was equivalent to $25.3 \%$ (or $20 \%$ ) of the total inorganic nitrogen inputs (TOxN + ammonium $=14.76+19.86=34.62 \mathrm{Mmol} \mathrm{N}$ in 1996; ammonium load was obtained by a calculation similar to that for nitrate load) into the estuary.

It is interesting that the percentage of $\mathrm{N}$ removed by denitrification from the total $\mathrm{N}$ load into an estuary varies in different estuaries. In a small, shallow estuary with a surface area of $1.86 \mathrm{~km}^{2}$ (the Norsminde Fjord, Denmark, Nielsen et al. 1995), only 2 to $3 \%$ of total $N$ load was removed from the estuary by denitrification, while in the Colne estuary with a surface area of $5.23 \mathrm{~km}^{2}, 20$ to $25 \%$ of the $\mathrm{N}$ load was removed by denitrification. The average annual rate of denitrification was only $0.23 \mathrm{~mol} \mathrm{~N} \mathrm{~m} \mathrm{Nr}^{-1}$ in the Norsminde Fjord, while it was $1.67 \mathrm{~mol} \mathrm{~N} \mathrm{~m} \mathrm{Nr}^{-2}$ in the Colne estuary, 7.3 times higher than that in the Norsminde Fjord. The lower rate of denitrification in the Norsminde Fjord was probably due to lower nitrate concentration in the water column, since from June to November 1992, nitrate concentrations were virtually zero. Moreover, at lower nitrate concentration, the ratio of nitrate reduction to ammonium to nitrate denitrified increased (King \& Nedwell 1987). Another possible reason for the lower $\mathrm{N}$ removal capacity in the Norsminde Fjord is the short freshwater flushing time (1.5 to $13 \mathrm{~d}$ ) and high total $\mathrm{N}$ load (307 $\mathrm{t} \mathrm{N} \mathrm{yr}^{-1}$ or 21.9 Mmol $\mathrm{N}$ in 1992: the proportion of nitrate in the total was not shown; it is possible that ammonium would comprise a larger proportion). The low rate of denitrification and high $\mathrm{N}$ load gave rise to a low percentage of $\mathrm{N}$ removed by denitrification (2 to $3 \%$ of the total $\mathrm{N}$ load). Even within any one estuary, the percentage of $\mathrm{N}$ removal by denitrification varies monthly. For instance, attenuation of the total oxidised nitrogen load varied from $1 \%$ in the middle of winter to $56 \%$ at the height of summer in the Great Ouse estuary, another estuary on the east coast of England (Trimmer et al. 1998).

The total nitrogen assimilated by benthic diatoms was estimated to be $0.81 \mathrm{Mmol} \mathrm{N} \mathrm{yr}^{-1}$ by multiplying the measured rates of net $\mathrm{O}_{2}$ production (assuming $\mathrm{O}_{2}: \mathrm{CO}_{2}=1: 1, \mathrm{C}: \mathrm{N}=10: 1$ and $6 \mathrm{~h}$ in the light for $1 \mathrm{~d}$ ) at each site in each month (from April 1997 to March $1998)$ by the exposed sediment area (28\% of the total sediment area) in each sector. It accounted for $2.3 \%$ of the total nitrogen inputs (or $4.1 \%$ of the total ammonium input) from the river and the sewage-treatment works into the estuary. It should be noted that the estimation of the total $\mathrm{N}$ assimilated by microphytobenthos is rather approximate, considering the possibility of wide deviations in the $\mathrm{C}: \mathrm{N}$ ratio and the seasonal cycle in daylength over the year.

A comparison of $\mathrm{N}$ denitrified by bacteria $\left(D_{\mathrm{w}}+D_{\mathrm{n}}\right)$ with $\mathrm{N}$ assimilated (using net $\mathrm{O}_{2}$ production, $\mathrm{C}: \mathrm{N}=$ 10:1) by microphytobenthos on a per unit area and per day basis can be made assuming that photosynthesis of microphytobenthos occurred during the daylight emersion period, defined as $6 \mathrm{~h} \mathrm{~d}^{-1}$ for Sites 1, $2 \mathrm{H}, 3 \mathrm{H}$ and 4 , and $3 \mathrm{~h}$ for Sites 2L and 3L. Fig. 12 shows that at Site 1 denitrification played an important role in removing nitrogen input from the estuary; at Site 2, denitrified $\mathrm{N}$ and assimilated $\mathrm{N}$ were similar; at Sites 3 (where chlorophyll a content in the sediment was the highest) assimilated $\mathrm{N}$ was much higher than denitrified $\mathrm{N}$; and at Site 4, assimilated $\mathrm{N}$ was higher than denitrified N. Most of the assimilated $\mathrm{N}$ will probably be mineralised and removed from the estuary by coupled nitrification-denitrification.

In conclusion, denitrification in this estuary played a significant role in attenuating nitrogen inputs from the river and the sewage-treatment works. Between 32 to $44 \%$ of TOxN inputs and 20 to $25 \%$ of the total inorganic nitrogen inputs ( $\mathrm{TOxN}+$ ammonium) into the estuary were removed from the estuary before being transported into the North Sea. The nitrate concentration in the water column seems to be the primary 


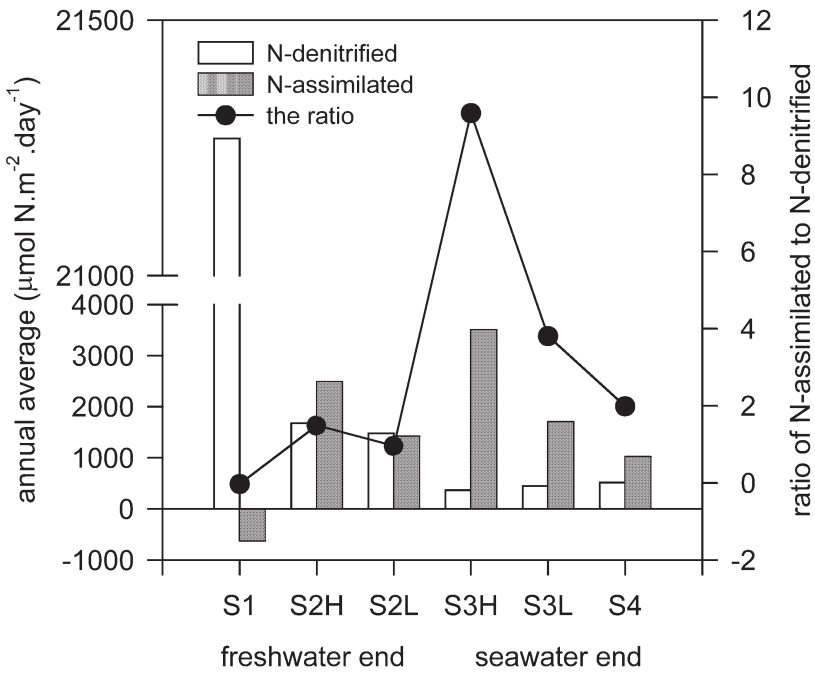

Fig. 12. Annual average of $\mathrm{N}$ denitrified by bacteria and $\mathrm{N}$ assimilated by microphytobenthos (on per unit area and per day basis) and ratio of $\mathrm{N}$ denitrified to $\mathrm{N}$ assimilated for all 6 sites in River Colne estuary

regulator of the rate of denitrification in this estuary. There were large unrealised potentials in the rates of denitrification at all sites in this estuary. Benthic primary producers, mainly diatoms, assimilated $2.3 \%$ of nitrogen input from the river and the sewage-treatment works, and temporarily retained the assimilated nitrogen in the estuary. They also affected the rates of denitrification in a complex manner. They regulated the depth of oxygen penetration by photosynthetic oxygen production and respiratory oxygen uptake. Oxygen inhibited the rates of $D_{\mathrm{w}}$ by increasing the length of the nitrate-diffusion path from the water column into the denitrifying zone (Fig. 9C), but stimulated $D_{\mathrm{n}}$ where availability of ammonium was not a limiting factor for nitrification (Fig. 9B).

Acknowledgements. This research was undertaken in the framework of the NICE project. We acknowledge the support from the European Commission's Marine Science and Technology Programme (MAST III) under Contract MAS 3-CT960048.

\section{LITERATURE CITED}

Aller RC (1982) The effects of macrobenthos on chemical properties of marine sediment and overlaying water. In: McCall PL, Tevesz MJS (eds) Animal-sediment relations. Plenum Press, New York, p 53-10

Balls PW (1994) Nutrient inputs to estuaries from nine Scottish East Coast rivers: influence of estuarine processes on inputs to the North Sea. Estuar Coast Shelf Sci 39:329-352

Billen G (1978) A budget of nitrogen recycling in North Sea sediments of the Belgian coast. Estuar Coast Mar Sci 7: 127-146

Billen G, Somville M, de Becker E, Servais P (1985) A nitrogen budget of the Scheldt hydrographical basin. Neth J Sea Res 19:223-230

Blackburn TH (1996) Nitrogen gas flux from sediments: insights from simulation modelling. Aquat Microb Ecol 10: 201-211

Broast CW, Mulvaney RL, Baveye P (1998) Evaluation of nitrogen-15 tracer techniques for direct measurements of denitrification in soil. 1. Theory. J Soil Sci Soc Am 52:1317-1322

Christensen PB, Nielson LP, Sørensen J, Revsbech NP (1990) Denitrification in nitrate-rich streams: diurnal and seasonal variation related to benthic oxygen metabolism. Limnol Oceanogr 35:640-652

Cooper M (1999) The influence of deposit feeding benthic fauna on biogeochemical fluxes across the estuarine sediment-water interface. MSc thesis, University of Essex, Colchester

Day JW, Hall CAS, Kemp WM, Yanez-Arancibia A (1989) Estuarine ecology. John Wiley \& Sons, New York

Garcia-Ruiz R, Pattinson SN, Whitton BA (1998) Kinetic parameters of denitrification in a river continuum. Appl Environ Microbiol 64:2533-2538

Gilbert F, Stora G, Bonin P (1998) Influence of bioturbation on denitrification activity in Mediterranean coastal sediments: an in situ experimental approach. Mar Ecol Prog Ser 163:99-107

Hansen JI, Henriksen K, Blackburn TH (1981) Seasonal distribution of nitrifying bacteria and rates of nitrification in coastal marine sediments. Microb Ecol 7:297-304

Henriksen K, Kemp W (1988) Nitrification in estuarine and coastal marine sediments. In: Blackburn TH, Sørenson J (eds) Nitrogen cycling in coastal marine environments. John Wiley \& Sons, New York, p 201-249

Henriksen K, Hansen JI, Blackburn TH (1981) Rates of nitrification, distribution of nitrifying bacteria, and nitrate fluxes in different types of sediment from Danish waters. Mar Biol 61:299-304

Jenkins MC, Kemp WM (1984) The coupling of nitrification and denitrification in two estuarine sediments. Limnol Oceanogr 29:609-619

King D, Nedwell DB (1985) The influence of nitrate concentration upon the end-products of nitrate dissimilation by bacteria in anaerobic salt marsh sediment. FEMS Microbiol Ecol 31:23-28

King D, Nedwell DB (1987) The adaption of nitrate-reducing bacterial communities in estuarine sediments in response to overlying nitrate load. FEMS Microbiol Ecol 45:15-20

Kirkwood DS (1996) Nutrients: a practical note on their determination in seawater. Techniques in marine environmental science, No. 17. ICES, Copenhagen

Koike I, Hattori A (1978) Denitrification and ammonia formation in anaerobic coastal sediments. Appl Environ Microbiol 35:278-282

Kristensen E (1984) Effect of natural concentrations of nutrient exchange between a polychaete burrow in estuarine sediment and the overlaying water. J Exp Mar Biol Ecol 75:171-190

Middelburg JJ, Soetaert K, Herman PMJ (1996) Evaluation of the nitrogen isotope-pairing method for measuring benthic denitrification: a simulation analysis. Limnol Oceanogr 41:1839-1844

Nedwell DB (1975) Inorganic nitrogen metabolism in an eutrophicated tropical estuary. Wat Res 9:221-231

Nedwell DB, Trimmer M (1996) Nitrogen fluxes through the upper estuary of the Great Ouse, England: the role of the bottom sediments. Mar Ecol Prog Ser 142:273-286

Nedwell DB, Jickells TD, Trimmer M, Sanders R (1999) Nutrients in estuaries. Adv Ecol Res 29:43-84 
Nielsen LP (1992) Denitrification in sediment determined from nitrogen isotope pairing. FEMS Microbiol Ecol 86: 357-362

Nielsen K, Nielsen LP, Rasmussen P (1995) Estuarine nitrogen retention independently estimated by the denitrification rate and mass balance methods: a study of Norsminde Fjord, Denmark. Mar Ecol Prog Ser 119:275-283

Nishio T, Koike I, Hattori A (1983) Estimation of nitrification and denitrification in coastal and estuarine sediments. Appl Environ Microbiol 45:444-450

Nixon SW, Ammerman JW, Atkinson LP, Berounsky VM, Billen G, Boicourt WC, Botnton WR, Church TM, DiToro DM, Elmgren R, Garber JH, Giblin AE, Jahnke RA, Owens NJP, Pilson MEQ, Seitzinger SP (1996) The fate of nitrogen and phosphorus at the land-sea margin of the North Atlantic Ocean. Biogeochemistry 35:141-180

Ogilvie B, Nedwell DB, Harrison RM, Robinson A, Sage A (1997) High nitrate, muddy estuaries as nitrogen sinks: the nitrogen budget of the River Colne estuary (United Kingdom). Mar Ecol Prog Ser 150:217-228

Pelegri SP, Blackburn TH (1995) Effect of bioturbation by Nereis sp., Mya arenaria and Cerastoderma sp. on nitrification and denitrification in estuarine sediments. Ophelia 42:289-299

Pelegri SP, Blackburn TH (1996) Nitrogen cycling in lake sediments bioturbated by Chironomus plumosus larvae, under different degrees of oxygenation. Hydrobiologia 325:231-238

Pelegri SP, Nielsen LP, Blackburn TH (1994) Denitrification in estuarine sediment stimulated by the irrigation activity of the amphipod Corophium volutator. Mar Ecol Prog Ser 105:285-290

Rhoads DC (1974) Organism-sediment relation on the muddy sea floor. Oceanogr Mar Biol Annu Rev 12:263-300

Editorial responsibility: Otto Kinne (Editor), Oldendorf/Luhe, Germany
Risgaard-Petersen N, Rysgaard S, Nielsen LP, Pevsbech NP (1994) Diurnal variation of denitrification and nitrification in sediment by colonized benthic microphytes. Limnol Oceanogr 39:573-579

Rysgaard S, Christensen PB, Nielsen LP (1995) Seasonal variation in nitrification and denitrification in estuarine sediment colonised by benthic microalgae and bioturbating infauna. Mar Ecol Prog Ser 126:111-121

Seitzinger SP (1988) Denitrification in freshwater and marine ecosystems: ecological and geochemical significance. Limnol Oceanogr 33:702-724

Seitzinger SP (1990) Denitrification in aquatic system. In: Revsbech NP, Sørensen J (eds) Denitrification in soil and sediment. Plenum Press, New York, p 301-322

Stal LJ, van Gemerden H, Krumbein WE (1984) The stimultaneous assay of chlorophyll and bacteriochlorophyll in natural microbial communities. J Microbiol Meth 2:295-306

Strickland JDH, Parsons TR (1972) A practical handbook of seawater analysis. Fisheries Research Board of Canada, Ottawa

Svensson JM (1998) Emission of $\mathrm{N}_{2} \mathrm{O}$, nitrification and denitrification in a eutrophic lake sediment bioturbated by Chironomus plumosus. Aquat Microb Ecol 14:289-299

Trimmer M, Nedwell DB, Sivyer DB, Malcolm SJ (1998) Nitrogen fluxes through the lower estuary of the river Great Ouse, England: the role of the bottom sediments. Mar Ecol Prog Ser 163:109-124

Underwood GJC, Paterson DM, Pakers RJ (1995) The measurement of microbial carbohydrate exopolymers from intertidal sediments. Limnol Oceanogr 40:1243-1253

Vanderborght JP, Billen G (1975) Vertical distribution of nitrate concentration in interstitial water of marine sediments with nitrification and denitrification. Limnol Oceanogr 20:953-961

Submitted: June 21, 1999; Accepted: March 28, 2000

Proofs received from author(s): August 22, 2000 